\title{
The Politics of Cash Transfers in Kenya
}

\author{
Ken Ochieng' Opalo \\ Georgetown University \\ Email: koo6@georgetown.edu
}

\begin{abstract}
How does public opinion on the causes of poverty and deservingness condition support for government support for the poor? This paper answers this question with a focus on direct cash transfers. I find minimal partisan differences in perceptions of the causes of poverty and deservingness, but significant differences in opinions on how to finance cash transfers. Supporters of the incumbent president are more likely to support increasing consumption taxes to finance these programs compared to opposition supporters. These findings suggest that partisan differences about social spending may exist even when there is agreement on the causes of poverty and deservingness.
\end{abstract}

Word Count: 7998 Words

Keywords: Partisanship, Distributive Politics, Social Protection, Cash Transfers, Kenya 


\section{Introduction}

As part of the global drive to end extreme poverty, cash transfers have become an important part of the social protection toolkit (ILO, 2010; Brooks, 2015). This is partially because studies from varied contexts highlight the benefits of cash transfers - including boosting individual self-efficacy and political empowerment (Devereux and Sabates-Wheeler, 2004; Bukenya, 2016) and improved outcomes in health, food security, nutrition, and education (Prifti, Daidone and Davis, 2019). Furthermore, direct cash transfers have been shown to be cheaper than in-kind transfers (Cunha, 2014). These findings have strengthened policymakers' belief in the efficacy of cash transfers, despite potential downsides (Hidrobo, Peterman and Heise, 2016; Torkelson, 2020) and the inherently imbalanced power dynamics that characterize policy transfer in this domain (Ouma, 2020). ${ }^{1}$

Cash transfer programs are ubiquitous in African states. In 2017 they accounted for 41 percent of total spending on social safety nets (Beegle, Coudouel and Monsalve, 2018, p. 7), with 46 countries having such programs. In comparison, 33 countries had workfare programs and 28 feeding programs. At their founding, most cash transfer programs in Africa were largely unconditional and heavily reliant on donors. Out of 87 programs across 24 countries in 2017, donor funding averaged 85.7 percent.

The predominance of donor-driven policy transfer in the sector raises important questions: Who deserves social protection through cash transfers in African states? And who should bear the costs of these programs? It is important to answer these questions for two reasons. First, while most existing social protection programs (including cash transfers) are donor-funded, African governments are increasingly taking on more financial responsibility. Second, the ongoing expansion of these programs will ineluctably increase their political salience. This will likely accentuate the impact of public opinion on program design and implementation. Therefore, to fully understand policy inputs and outcomes in this sector one must pay attention to public opinion. 
Using a nationally representative survey from Kenya, I analyze respondents' views on (i) the causes of poverty, (ii) specific groups' deservingness of social assistance through direct cash transfers, and (iii) how cash transfers programs ought to be financed. I focus on cash transfers, instead of other forms of social protection like school feeding and health insurance, because of the salience of redistributive aspects of direct cash transfers. I find that respondents largely attribute poverty to the lack of jobs (42.3 percent) and government corruption (24.8 percent). A much smaller proportion cites bad luck (1.8 percent). On deservingness, 37 percent of respondents choose orphans, 32 percent the disabled, 21 percent the elderly, and 9 percent the unemployed. While respondents view unemployment as the leading cause of poverty, little support exists for social insurance for the unemployed. There are no significant partisan differences on either the causes of poverty or deservingness of government assistance through cash transfers.

However, the data show strong correlations between partisanship and opinions on how to finance cash transfer programs. Co-partisans of the incumbent president are more likely to support increasing the value added tax (VAT) and increasing taxes on everyone (as opposed to just the wealthy or taxing no one) to finance cash transfer programs. I attribute this partisan divergence to varying levels of trust and perceived legitimacy of the government, in part due to Kenya's long history of presidential (ethnic) favoritism in the provision of public goods and services. Regression analyses show that these differences are not driven by beliefs about causes of poverty or deservingness.

It is important to understand how beliefs about causes of poverty and deservingness interact with support for public spending on cash transfers in contexts like Kenya. For instance, Dawson and Fouksman (2020) document the discourse on lazy welfare grant recipients and deservingness in South Africa. Similarly, in the United States, racialized beliefs about the causes of poverty and deservingness are correlated with opposition to welfare spending (Hussey and Pearson-Merkowitz, 2011). In Kenya, I find that partisanship is not a strong predictor of opinions about the causes of poverty and deservingness, but conditions views 
on how anti-poverty programs should be financed. ${ }^{2}$ Understanding the politics of financing is important because it can often be a weak link in the adoption of broad-based social protection programs (Ikiara, 2009; Abuya, Maina and Chuma, 2015) - in part by structuring politicians' willingness to invest in these programs either in anticipation of or in response to public opinion. As Wanyama and McCord (2017) document, despite significant donor funding and technical support, political considerations have informed the design and implementation of social protection programs in Kenya.

This paper contributes to the rich literature on the political economy of social protection in African states (Hickey et al., 2019). This includes works on the economic and social consequences of targeting cash transfers (Ellis, 2012; Pavanello et al., 2016); the politics of global policy transfer and local ownership (Adesina and Ouma, 2019; Ouma, 2020); public opinion on social assistance and impacts on voting behavior in South Africa (Seekings, 2002; Graham, Sadie and Patel, 2016; Plagerson et al., 2019; Torkelson, 2020); the ideological motivations for social welfare policy design in Botswana (Good, 1999); how mutual interdependence and links between elites and the poor shape preferences for social welfare policy in Malawi (Kalebe-Nyamongo, 2010) and Rwanda (Ansoms, 2009); individual-level attitudes about welfare targeting in Zambia (Schuring, 2014); and Ethiopia's developmentalist approaches to social protection (Lavers, 2019; Aalen, 2019). These works highlight the different dynamics of social protection policies in countries with established social welfare infrastructures like Botswana and South Africa, as well as those that are in the process of building welfare systems, often with the help of donors.

Kenya fits in the latter category. It is rapidly expanding its social assistance programs, while at the same time decreasing its reliance on donors - with cash transfers comprising about 83 percent of social assistance. Between 2007-2016 government outlays increased from 15 percent to almost 70 percent of program costs (see Figure 1), with future expansions of these programs expected to be tax-financed (Government of Kenya, 2017, p. 72). Beyond questions about global policy transfer and local ownership (Ouma, 2020), bigger 
domestically-funded budgets for cash transfers will likely increase the salience of their distributive implications. Finally, Kenya has hosted several studies of the economic impacts of direct cash transfers, including a large 12-year study covering 14,474 households. ${ }^{3}$

The next section outlines a framework for understanding individual-level attitudes on the causes of poverty, deservingness, and government spending on social protection. Section 3 describes the social protection terrain in Kenya. Section 4 analyzes data on the correlates of beliefs about the causes of poverty, deservingness, and financing of cash transfers. Section 5 concludes and discusses potential avenues for future research on public opinion and social protection in African states.

\section{Distributive Politics and Cash Transfer Programs}

\subsection{Global Policy Diffusion and Local Politics}

Since 1990 African states have witnessed several examples of policy diffusion through global compacts like the Millennium Development Goals and the Sustainable Development Goals. At the same time, efforts to domesticate these compacts have been conditioned by domestic politics. Electoral competitiveness have been associated with increases in the provision of public goods and services to meet international compacts in sectors as diverse as agriculture (Dionne and Horowitz, 2016), education (Stasavage and Harding, 2014), and healthcare (Carbone, 2011). While international policy diffusion and donor funding were critical in the initial phases of reforms in different sectors, domestic politics explain the variation in timing and policy design across African states.

Social protection programs are not different. The diffusion of cash transfer programs and heightened electoral competitiveness have "forced poverty and social protection concerns onto domestic policy agendas" (Devereux and White, 2010, p. 63). While originally largely donor-funded, these programs are nonetheless shaped by politics. For instance, Ghana's 
Livelihood Empowerment Against Poverty (LEAP) program was partly inspired by Brazil's Bolsa Familia program and supported by the World Bank, the United Nations Children's Fund (UNICEF), and the British Department of International Development (DFID). Yet its design and implementation was rushed "just a few months before the December 2008 presidential election [in] an attempt by the government to showcase new efforts to reduce poverty" (Davis et al., 2016, p. 148-9).

Another illustrative example is Ethiopia's Productive Safety Net Programme (PSNP). The 2002/03 Ethiopian food crisis catalyzed reforms to boost food security. Consequently, the government and donors planned to wean the country off of food aid, and adopt a cashbased social safety net program for vulnerable populations. While donors preferred to pilot an unconditional cash transfer program, the government insisted on an at-scale rollout with a workfare component (designed to preempt concerns about dependency). ${ }^{4}$ Importantly, the PSNP program was launched in February 2005, ahead of elections in May, with an enrollment of over 4.5m (Sharp, Brown and Teshome, 2006; Desalegn and Ali, 2018; Lavers, 2019).

These examples highlight the importance of understanding domestic politics of social protection policy design, despite donors' outsize roles. Scholars of policy diffusion emphasize the importance of understanding "how policies or practices are altered during processes of adoption" (Stone, 2012, p. 485). While not principally about policy diffusion, this paper contends that despite initial donor dominance of anti-poverty social protection through direct cash transfers, these programs have invariably been shaped by politicians' concern

about public opinion during implementation. Therefore, it is important to understand the underlying drivers of individual-level opinions on these programs.

\subsection{Politics and Public Opinion on Cash Transfers}

Efforts by government to reduce poverty and tackle sources of economic and health-related vulnerability (social protection) have increasingly become part of government policy in many 
African states. Cash transfers, in particular, are widely favored and often target recipients below specific poverty thresholds (e.g. earning less than USD 2 per day) or other criteria. Two factors may drive public opinion on cash transfer programs. First, trust in government may condition opinions on policy, including support for government spending on redistributive programs (Hetherington, 2004; Rudolph and Evans, 2005). Therefore, the existence of a broad-based social contract on the back of government legitimacy and effectiveness may predispose individuals to support cash transfer programs (Hickey and King, 2016). Conversely, corruption, incompetence, and lack of legitimacy may erode public support for these programs. Second, perceptions about who deserves assistance (deservingness) of beneficiaries matter (Kalebe-Nyamongo, 2010; Dawson and Fouksman, 2020). Views on deservingness may be driven by socially-constructed neediness of particular groups like orphans, the physically disabled, or the elderly; identification with potential recipients of assistance (e.g. along religious, ethnic, or class lines); and beliefs about the causes of poverty - such as laziness or luck (Gilens, 1996; Kulin and Svallfors, 2013). In the same vein, beliefs about the causes of poverty may be driven by individual and societal-level priors about how personal behavior and structural conditions shape life outcomes (Cozzarelli, Wilkinson and Tagler, 2001).

Institutional and ideological features of social protection regimes and state capacity may interact with the above factors to condition public perceptions of cash transfer programs. For example, Plagerson et al. (2019) describe structural constraints to the implementation of robust social policies in South Africa, despite strong constitution guarantees. Such structural constraints may limit the scope of cash transfer programs in ways that shape public opinion. Evidence shows that public support for redistributive programs is stronger for universal programs compared to targeted programs (Rothstein, 2001; Moene and Wallerstein, 2003; Larsen, 2008). Furthermore, exposure to government welfare programs shapes public opinion and attitudes. Programs like Brazil's Bolsa Família (Hunter and Sugiyama, 2014), Mexico's Oportunidades (De La O, 2013), the GI Bill and Social Security in the United States (Campbell, 2003; Mettler, 2005), and cash transfers in Tanzania (Evans, Holtemeyer 
and Kosec, 2019) have been shown to influence citizens' participation, willingness to pay taxes, and perceptions of government legitimacy.

A number of observable implications arise from the above discussions. Due to established social norms, individuals may view orphans, the physically disabled, and the elderly to be more deserving of social assistance compared to able-bodied people of working age. Similarly, co-ethnics or co-religionists may be viewed as more deserving than perceived out-groups. Structural factors like perceptions of government legitimacy, fiscal probity, impartiality, and effectiveness may also influence public opinion on whether the state should provide social assistance to needy groups. The impacts of these structural factors are likely to be correlated with partisan affiliation. Finally, concerns about redistribution may predispose higher income individuals, or those for whom taxation is more salient, to be less likely to support taxfinanced government spending on social welfare programs such as cash transfers.

A number of factors may drive public opinion on cash transfers in Kenya. First, it has a history of ethnic favoritism in the provision of public goods (Ajulu, 2002; Ndegwa, 1997) and high levels of corruption (D'Arcy and Cornell, 2016). According to the Afrobarometer Survey, 52.4 percent of respondents reported the existence of ethnic discrimination by the government. ${ }^{5}$ Therefore, the erosion of government legitimacy due to perceived partisan/ethnic favoritism may influence public opinion on causes of poverty, deservingness, and the financing of direct cash transfers. Second, while cash transfers comprise the bulk of spending on social assistance, the programs are not yet universal (Porisky, 2020). The geographical variation in program intensity is likely to create perceptions of regional redistribution. Finally, only a small proportion (17.1 percent) of Kenyans are employed in formal wage jobs, with the vast majority working in agriculture or informal occupations that are hard to tax directly. ${ }^{6}$ Consequently, tax incidence for most Kenyans takes the form of indirect consumption taxes such as the Value Added Tax (VAT). As elaborated below, the dominance of indirect taxes and the leading role of cash transfers in Kenya inform the empirical approach in this paper. 


\section{Cash Transfer Programs in Kenya}

This section provides a justification for studying individual-level attitudes towards cash transfers in Kenya. Like other African states, Kenya's social safety net programs emerged from the intersection of international policy trasnfer and domestic politics. In the early 2000s Kenya had the second highest number of orphans in Africa (over 1.5m), in large part due to the HIV/AIDs epidemic (Alviar and Pearson, 2009). Furthermore, the country's arid and semi-arid lands (ASALs) repeatedly experienced drought thus requiring food relief. Government investments in social protection was also partially motivated by the breakdown of family-based social insurance systems. ${ }^{7}$ These local conditions, in interaction with donordominated global anti-poverty agendas, resulted in the creation of programs such as the Hunger Safety Net Program (HSNP) and the Cash Transfer-Orphans and Vulnerable Children (CT-OVC) program.

The evolution of Kenya's CT-OVC program is instructive. Political commitment to the program preceded the 2002 election - thanks to the "Call to Action" campaign by the United Nations Children's Fund (UNICEF). ${ }^{8}$ More than 100 of the candidates who signed UNICEF's 12 pledges were elected in 2002 and formed a Standing Committee on OVC. The Ministry of Home Affairs then formed a National Steering Committee on OVC. Between 2004-06, the government and UNICEF piloted the program among 500 households. With additional funding from the United Kingdom, by 2008 the program expanded to include more than 75,000 households. A year later, the Kenyan government had become the biggest funder of the program (Alviar and Pearson, 2009).

Table 1 here

Members of Parliament (MPs) pressured the government throughout the piloting phase

of the CT-OVC program, demanding an immediate national rollout. One MP argued that "the issue of orphans and vulnerable children [in Kenya] is a bomb that we are holding 
in our hands."9 Another MP noted that the "plight of orphans is a national crisis and a matter of urgency. It cannot be piloted", with yet another adding that "the problem facing orphans cannot wait for research work to be completed". ${ }^{10}$ Similar to Ethiopia's PSNP, once the program started, the political demand was for immediate implementation at scale. This suggests that politicians were reacting to or anticipated specific public reactions to CT-OVC and similar cash transfer programs - hence the need to understand public opinion on these programs.

In addition to the CT-OVC, Kenya has a diverse portfolio of social protection programs (see Table 1). 83\% of social assistance programs take the form of cash transfers. By 2017 about 813,381 households nationwide were receiving some form of cash transfers. ${ }^{11}$ Other forms of social protection include contributory retirement schemes, health insurance, and in-kind social assistance (including emergency relief). In 2016, more than one million households received some form of social assistance from the government. This figure excludes $1.7 \mathrm{~m}$ children that were beneficiaries of the school feeding program and over 800,000 seniors (individuals over 70 years old) who are eligible for transfers under the Inua Jamii Senior Citizens' Scheme.

Kenya's social protection system is "currently focuses on addressing the needs of two groups: those living in the most extreme poverty and the more affluent" (Government of Kenya, 2017, p. 51). Existing programs only cover the bottom 5 percent and the top 20 percent of the income distribution. The top of the distribution is covered by contributory programs and health insurance schemes, while the bottom of the distribution receives cash transfers through the various programs listed in Table 1. These programs fall short of operating as entitlements, partly because of their humanitarian/donor-funded origins. Due to Kenya's economic geography, the various social protection programs tend to have regional specificity. Coverage by any form of social protection in ASALs and non-ASALs is 12 percent and 7 percent of households, respectively.

Layered on top of these programmatic features and geographical differences is a politi- 
cal history of fractious ethnic politics characterized by presidential abuse of power (Opalo, 2020) and explicit ethnic favoritism in the provision of public goods and services and access to public sector jobs (Ajulu, 2002; Ndegwa, 1997; Kramon and Posner, 2016). ${ }^{12}$ The salience of ethnicity as the primary means of organizing politics and targeting of government services is reflected in public opinion. According to the latest available Afrobarometer Survey (2016-2018), only 42.3 percent of respondents reported feeling that members of their ethnic group are never treated unfairly by the government. It's also instructive that co-ethnics of the incumbent president during this period (Kikuyus) report the lowest levels of perceived discrimination, while co-ethnics of the leader of opposition (Luos) report the highest levels.

Potential demand for expanding social protection programs remains high in Kenya. In 2016 the national poverty headcount rate was 36.1 percent, with higher rates in rural (40.1 percent) than urban areas (27.5 percent). 22.9 percent of the poor live in households headed by persons over the age of 60 years. Across the country, the reported child poverty was 41.5 percent. Food poverty is high, with 14.5 million individuals (32 percent) reported to be below the food poverty line of at least 2,350 Kcal per day. 8.6 percent of individuals lived in extreme poverty, unable to meet their daily calorific requirements even if they allocated their expenditures exclusively to food (KNBS, 2018).

The above features of the social protection terrain in Kenya inform this paper's empirical focus on cash transfers and the VAT. Given the portfolio of social protection programs in Table 1, cash transfers have the advantage both of being highly salient and embodying the redistributive nature of social welfare programs. Unlike universal programs like old age pension, health insurance, or school feeding for which inherent redistributive features are not always readily apparent, cash transfers specifically target needy households. ${ }^{13}$ The operationalization of potential tax contribution to finance social assistance as VAT is informed by the fact that the vast majority of working age Kenyans do not have wage-earning jobs and therefore do not pay income taxes. Instead, most pay consumption taxes through VAT. ${ }^{14}$ 


\section{Data and Analysis}

\subsection{Public Opinion on Cash Transfers in Kenya}

To examine public opinion on the causes of poverty, deservingness, and how cash transfers

should be financed, I use data $(\mathrm{N}=2015)$ from a nationally-representative omnibus survey conducted by IPSOS, a survey firm, between July 25 and August 2, 2018. The survey asked respondents of voting age a series of questions about the economy and contemporary politics. Included in the survey were bespoke questions on cash transfers. The analyses herein focus on questions relevant to the subject of cash transfers and examine the correlates of public opinion on poverty, deservingness, and public finance of cash transfers. These data are a contribution to our understanding of the politics of cash transfers in Kenya.

Table 2 here

Table 2 summarizes key variables of interest. Respondents' mean age is 34.2 years, 50.9 percent are female, 35 percent live in urban areas, 28.7 percent are single, while only 17.3 percent have wage income. Education (1-10) and income (1-14) are operationalized on interval scales. The median respondent has had "some secondary" education, while 38 percent completed primary school. The median income is between 10,001-25,000 shillings per month (U.S. \$100-250), while 39.2 percent of respondents make less than 10,000 shillings per month (\$100). 85.5 percent of respondents voted in 2017 , while 49.2 percent voted for the incumbent president. 29.6 percent support increasing the value added tax (VAT) to finance cash transfers. 19.7 percent agreed with taxing everyone, as opposed to just the wealthy or no tax at all. Finally, 23.8 percent of the respondents are Catholic, 40.3 percent belong to mainline protestant denominations, while 8.6 percent are Muslim.

Figure 2 here

Figure 3 here 
Figures 2 and 3 show opinions from partisan respondents, who reported voting either for the incumbent president or another candidate in $2017 .{ }^{15}$ On the question of causes of poverty, respondents were given the choices shown in Figure 2 and requested to give a single response. ${ }^{16}$ Overall, a majority respondents believe that a lack of jobs, government corruption, and the lack of government assistance are the leading causes of poverty. Interestingly, opposition supporters are more likely to attribute a lack of jobs as a cause of poverty, relative to supporters of the incumbent administration. This is probably because opposition supporters were less likely to pick the "other" or "not sure" categories and are more likely to reside in urban areas where wage-jobs are more important than rural areas. 27.1 percent of supporters of the incumbent party reside in urban areas, compared to 42.9 percent of opposition supporters.

To solicit views on deservingness, voters were given six choices shown in Figure 3. The question forced respondents to choose between direct assistance to needy categories and indirect assistance to the unemployed. ${ }^{17}$ The data show cross-partisan agreement in the deservingness of the unemployed and orphans. The only evident partisan difference is in the choice of the elderly versus the disabled. Relative to supporters of the incumbent party, opposition supporters are more likely to pick the elderly than the disabled. ${ }^{18}$ Figure 3 shows that despite the recognition of the lack of jobs as a major cause of poverty, there is relatively little support for providing social assistance for the unemployed regardless of partisanship. This respondents' preference for targeted cash transfers to well-defined "deserving poor" categories, as opposed to generalized social protection for households based on income or employment status.

Figure 4 here

Next, I examine public opinion on how cash transfers should be financed. Figure 4 shows the distribution of views on taxation to finance cash transfer programs. ${ }^{19}$ Unsurprisingly, more than 60 percent of respondents would like the rich to bear most of the burden of social 
protection through cash transfers. However, partisanship is a strong moderator of views on taxation. On both the question on VAT (left panel) and that comparing consumption taxes vs taxing the rich (right panel), co-partisans of the incumbent president are more likely to support taxes than opposition supporters. These differences are remarkable, especially since there are no significant partisan differences in beliefs about both causes of poverty and deservingness; and because the survey question included the options to oppose taxes altogether and to tax the rich. Relative to opposition supporters, co-partisans/co-ethnics of the incumbent president are more likely trust the government with their tax shillings.

Regression analyses corroborate the above summaries. I focus on the correlation between support for higher taxes to fund cash transfers and partisanship. I operationalize partisanship as respondents' reported vote for president Uhuru Kenyatta in the 2017 election. ${ }^{20}$ Across different models, I add a number of control variables that may be correlated with views on taxation. These include having a wage income, age, gender, urban residence, income, and education attainment. I also control for religion and opinions on deservingness and causes of poverty in the full model. The results from logit regressions are shown in Tables 3 and $4 .^{21}$

\section{Table 3 here}

I begin by examining the correlates of support for increasing the value added tax to finance direct cash transfers (Table 3). The results show that respondents who voted for the incumbent are more likely to support increasing VAT to finance direct cash transfers. This finding is consistent across multiple specifications. In the appendix, I also operationalize the outcome as opposition to VAT increase, and find similar (i.e. reverse) results (see Table A8 in the Appendix). Partisans of opposition candidates are more likely to oppose a VAT increase compared to supporters of the incumbent president. In addition, being older, a wage earner, or having attained a higher level of education are negatively correlated with support for increasing VAT to finance cash transfers. This is likely due to the high salience of tax incidence among respondents with these characteristics. These findings are robust 
to controlling for levels of income. Finally, being female or living in an urban area are not statistically correlated to views on increasing VAT to finance cash transfers.

\section{Table 4 here}

Figure 5 here

Figure 6 here

Partisanship is also correlated with support for increasing consumption taxes on everyone (as opposed to targeted taxation of the rich or no tax at all) in order to finance direct cash transfers. Table 4 shows the results. Across different specifications, supporters of the incumbent president are more likely to support increasing consumption taxes on everyone. Conversely, opposition supporters are less likely to support tax increases on everyone, but more likely to support targeted tax increases on the rich. ${ }^{22}$ Older respondents are less likely to support increasing consumption taxes on everyone, likely due to the high salience of tax incidence among older and higher income respondents. Finally, female respondents are more likely to support increasing taxes on the rich, as opposed to everyone or not raising taxes at all. These results are robust to controlling for reported causes of poverty, deservingness of particular groups, and religion.

Figures 5 and 6 shows predictive margins of reported causes of poverty (left graph) and deservingness (right graph) using the specification in Column 6 of Tables 3 and 4, respectively. ${ }^{23}$ Supporters of the incumbent president are more likely to support increasing VAT or the taxation of everyone to finance cash transfers regardless of views on the cause of poverty and deservingness. Overall, the data from Kenya suggest that partisanship conditions views on how social protection through direct cash transfers ought to be financed. In particular, citizens' mistrust of incumbent politicians or doubts regarding government administrative fairness in the provision of social protection through cash transfers are correlated with partisan polarization regarding how cash transfers should be financed. 


\section{Conclusion}

As African states expand cash transfers programs and reliance on domestic financing, politicians will be forced to grapple with the distributive politics of these programs. Ideas about causes of poverty, deservingness, and redistribution will likely shape public opinion about cash transfers. By closely examining patterns of public opinion on the causes of poverty, deservingness, and the financing of cash transfers in Kenya, this paper contributes to the literature on the political economy of social protection in general, and cash transfers in particular. These findings raise new questions that should inform future research on public opinion on social protection in African states - including impacts on citizens' civic attitudes, tax compliance, political attribution, and general support for redistribution.

The need for more research is underscored by the relative novelty and scope of social protection programs in African states. While a number of countries in Southern Africa have fairly established social protection programs (including cash transfers), most of the region

has relatively new programs. This provides an opportunity to interrogate the evolution of these programs from the perspective of both global policy transfer and domestic politics. In addition to exploring questions about program efficacy, future works should pay attention to how public opinion shape policy choice, the selection of beneficiaries, and the trajectories of expansion of these programs. 


\section{Notes}

${ }^{1}$ According to the World Bank's ASPIRE administrative database, 70 percent of states worldwide administer unconditional cash transfers and 43 percent have conditional cash transfers (World Bank, 2018).

${ }^{2}$ The weak correlation between partisanship and attitudes about deservingness may be due to Kenyan parties' high volatility and lack of strong (left-right) ideological brands (Elischer, 2013; Opalo, 2019); while the partisan division on how to finance the programs may be due to Kenya's history of presidential/ethnic favoritism (Ajulu, 2002; Kramon and Posner, 2016).

${ }^{3}$ See "The Effects of a Universal Basic Income in Kenya", Innovation for Poverty Action

${ }^{4}$ In this regard, Ethiopia's government resembled other African counterparts that have shown a bias towards workfare programs (Good, 1999; Ellis, Devereux and White, 2009).

${ }^{5}$ Afrobarometer Survey, Round 7

${ }^{6}$ Kenya National Bureau of Standards, Statistical Abstract, 2019

${ }^{7}$ Government of Kenya, Interim Poverty Reduction Strategy Paper 2000-2003

${ }^{8}$ See "Kenya's 1.2m AIDS orphans at the Center of the 2002 Election Agenda," Inter Press Service, November 27, 2002.

${ }^{9}$ Government of Kenya, Kenya National Assembly Official Record, October 6, 2004. Col. 3419

${ }^{10}$ Government of Kenya, Kenya National Assembly Official Record, August 10, 2005. Col. 3094.

${ }^{11}$ Partnership for African Social \& Governance Research, Policy Brief No. 002, June 2017

${ }^{12}$ For example, the incumbent administration is dominated by Kkikuyus and Kalenjins, co-ethnics of President Uhuru Kenyatta and his deputy William Ruto, respectively. See "Kikuyu, Kalenjin, Luhya and Luo dominate public service jobs," The Star, September 3, 2020 
${ }^{13}$ This is consistent with the idea that "direct cash or in-kind transfers" elicit ambivalent support, unlike universal programs that enjoy unanimous public support (Gilens, 1996, p. 593-4).

${ }^{14}$ Kenya National Bureau of Standards, Statistical Abstract, 2019

${ }^{15} 1,718$ individuals report their partisan leanings in the survey, 57.7 percent of whom voted for the incumbent president Uhuru Kenyatta in 2017.

${ }^{16}$ The question asked "What do you think is the main reason why some people in Kenya are very poor?"

${ }^{17}$ The question asked: "Recently, the government has begun a program to transfer cash to poor Kenyans through mobile phones. In your opinion, which of the following groups of people deserve the most to receive this kind of government assistance?"

${ }^{18}$ This might be because opposition supporters are more likely to be urban dwellers who face greater pressure to send remittances to help older relatives residing in rural areas (Jack and Suri, 2014; Jena, 2018).

${ }^{19}$ On increasing VAT, respondents were asked" "Would you support an increase in VAT taxes on general goods in order to enable the government to support groups of people through cash transfer programs via mobile phones?" And on taxation of the rich vs everyone else, they were asked to pick between two statements: Which of the following statements do you agree with the most? (A) The government should raise taxes on everyone by increasing the prices of items like sugar, unga (flour), and salt, in order to help groups of people in need through cash transfer programs via mobile phones; and "The government should increase taxes only on the very rich people in order to help those in need through cash transfers programs via mobile phones."

${ }^{20}$ Reported voting behavior is a more reliable marker of partisanship in Kenya. The country's party system is highly volatile and politicians often change parties between elections (Opalo, 2019, p. 222-223). The results are the same when I operationalize partisanship as reported closeness to a particular party. 
${ }^{21}$ Ordinary least squares (OLS) regressions provide similar results. See Tables A4-A7 in the Appendix.

${ }^{22}$ Table A9 in the Appendix shows results with the choice of taxing only the rich as the dependent variable; with opposition supporters more likely to support exclusive taxation of the rich.

${ }^{23}$ Reported causes of poverty and deservingness are included in the specifications as factor variables. 


\section{References}

Aalen, Lovise. 2019. "The Revolutionary Democracy of Ethiopia: A Wartime Ideology Both Shaping and Shaped by Peacetime Policy Needs." Government and Opposition pp. 1-16.

Abuya, Timothy, Thomas Maina and Jane Chuma. 2015. "Historical Account of the National Health Insurance Formulation in Kenya: Experiences from the Past Decade." BMC Health Services Research 15(56):1-11.

Adesina, Jimi and Marion Ouma. 2019. "Solutions, exclusion and influence: Exploring power relations in the adoption of social protection policies in Kenya." Critical Social Policy $39(3): 376-395$.

Ajulu, Rok. 2002. "Politicised Ethnicity, Competitive Politics and Conflict in Kenya: A Historical Perspective." African Studies 61(2):251-268.

Alviar, Carlos and Roger Pearson. 2009. "Cash Transfers for Vulnerable Children in Kenya: From Political Choice to Scale Up." Social and Economic Policy Working Paper.

Ansoms, An. 2009. "Re-Engineering Rural Society: The Visions and Ambitions of the Rwandan Elite." African Affairs 108(431):289-309.

Beegle, Kathleen, Aline Coudouel and Emma Monsalve, eds. 2018. Realizing the Full Potentialof Social Safety Nets in Africa. World Bank Group.

Brooks, Sarah M. 2015. "Social Protection for the Poorest: The Adotion of Antipoverty Cash Transfer Programs in the Global South." Politics 65 Society 43(4):551-582.

Bukenya, Badru. 2016. "From Social Accountability to a New Social Contract? The Role of NGOs in Protecting and Empowering PLHIV in Uganda." Journal of development Studies 52(8):1162-1176.

Campbell, Andrea Louise. 2003. How Politics Make Citizens: Senior Political Activism and the American Welfare State. Princeton, NJ: Princeton University Press.

Carbone, Giovanni. 2011. "Democratic Demands and Social Policies: The Politics of Health Reform in Ghana." Journal of Modern African Studies 49(3):381-408.

Cozzarelli, Catherine, Anna V. Wilkinson and Michael J. Tagler. 2001. "Attitudes Toward the Poor and Attributionsfor Poverty." Journal of Social Issues 57(2):207-227.

Cunha, Jesse M. 2014. "Testing Paternism: Cash Versus In-Kind Transfers." American Economic Journal: Applied Economics 6(2):195-230.

D'Arcy, Michelle and Agnes Cornell. 2016. "Devolution and Corruption in Kenya: Everyone's Turn to Eat?" African Affairs 115(459):246-273. 
Davis, Benjamin, Sudhanshu Hand, Nicola Hyper, Natalia W. Rossi, Paul Winters and Jennifer Jablonski. 2016. From Evidence to Action: The Story of Cash Transfers and Impact Evaluation in Sub Saharan Africa. Oxford, UK: Oxford University Press.

Dawson, Hannah J. and Elizaveta Fouksman. 2020. "Labour, Laziness and Distribution: Work Imaginaries Among the South African Employed." Africa 90(2):229-251.

De La O, Ana L. 2013. "Do Conditional Cash Transfers Affect Electoral Behavior? Evidence from a Randomized Experiment in Mexico." American Journal of Political Science 57(1):114.

Desalegn, Gashaw and Seid Nuru Ali. 2018. "Review of the Impact of Productive Safety Net Program (PSNP) on Rural Welfare in Ethiopia." Working Paper, 173 Center for Development and Research, University of Bonn pp. 1-36.

Devereux, Stephen and Philip White. 2010. "Social Protection in Africa: Evidence, Politics, Rights." Poverty \& Politics 2(3):53-77.

Devereux, Stephen and Rachel Sabates-Wheeler. 2004. "Transformative Social Protection." IDS Working Paper No. 232 pp. 1-36.

Dionne, Kim Yi and Jeremy Horowitz. 2016. "The Political Effects of Agricultural Subsidies in Africa: Evidence from Malawi." World Development 87:215-226.

Elischer, Sebastian. 2013. Political Parties in Africa: Ethnicity and Party Formation. Cambridge, UK: Cambridge University Press.

Ellis, Frank. 2012. "We Are All Poor Here': Economic Difference, Social Divisiveness and targeting Cash Transfers in Sub-Saharan Africa." Journal of Development Studies $48(2): 201-214$.

Ellis, Frank, Stephen Devereux and Philip White. 2009. Social Protection in Africa. Cheltenham, UK: Edward Elgar.

Evans, David K., Brian Holtemeyer and Katrina Kosec. 2019. "Cash Transfers Increase Trust in Local Government." World Development 114:138-155.

Gilens, Martin. 1996. "“Race Coding" and White Opposition to Welfare." American Political Science Review 90(3):593-604.

Good, Kenneth. 1999. "The State and Extreme Poverty in Botswana: the San and Destitutes." Journal of Modern African Studies 37(2):185-205.

Government of Kenya. 2017. Kenya Social Protection Sector Review. Nairobi, Kenya: Government of Kenya.

Graham, Victoria, Yolanda Sadie and Leila Patel. 2016. "Social Grants, Food Parcels and Voting Behavior: A Case Study of Three South African Communities." Transformation: Critical Perspectives on Southern Africa 91:106-135. 
Hetherington, Marc J. 2004. Why Trust Matters: Declining Polit-ical Trust and the Demise of American Liberalism. Princeton, NJ: Princeton University Press.

Hickey, Sam and Sophie King. 2016. "Understadning Social Accountability: Politics, Power, and Building Social Contracts." Journal of Development Studies 52(8):1225-1240.

Hickey, Sam, Tom Lavers, Miguel Nino-Zarazua and Jeremy Seekings, eds. 2019. The Politics of Social Protection in Eastern and Southern Africa. Oxford, UK: Oxford University Press.

Hidrobo, Melissa, Amber Peterman and Lori Heise. 2016. "The Effect of Cash, Vouchers, and Food Transfers on Intimate Partner Violence: Evidence from a Randomized Experiment in Northern Ecuador." American Economic Journal: Applied Economics 8:284-303.

Hunter, Wendy and Natasha Borges Sugiyama. 2014. "Transforming Subjects into Citizens: Insights from Brazil's Bolsa Familia." Perspectives on Politics 12(4):829-845.

Hussey, Laura S. and Shanna Pearson-Merkowitz. 2011. "The Changing Role of Race in Social Welfare Attitude Formation: Partisan Divides over Undocumented Immigrants and Social Welfare Policy." Political Research Quarterly 66(3):572-584.

Ikiara, Gerrishon K. 2009. "Political Economy of Cash Transfers In Kenya." Overseas Development Institute pp. 1-34.

ILO. 2010. "Effects of Non-Contributory Social Transfers in Developing Countries: A Compendium." International Labor Organization .

Jack, William and Tavneet Suri. 2014. "Risk Sharing and Transaction Costs: Evidence from Kenya's Mobile Money Revolution." American Economic Review 104(1):183-223.

Jena, Farai. 2018. "Migrant Remittances and Physical Investment Purchases: Evidence from Kenyan Households." Journal of development Studies 54(2):312-326.

Kalebe-Nyamongo, Chipiliro. 2010. "Mutual Interdependence Between Elites and the Poor." UNU-WIDER Working Paper No. 2010/117 pp. 1-23.

KNBS. 2018. Basic Report on Well-Being in Kenya, Based on the 2015/16 Kenya Integrated Household Budget Survey (KIHBS). Nairobi, Kenya: Government of Kenya.

Kramon, Eric and Daniel Posner. 2016. "Ethnic Favoratism in Education in Kenya." Quarterly Journal of Political Science 11(1):1-58.

Kulin, Joakin and Stefan Svallfors. 2013. "Class, Values, and Attitudes Towards Redistribution: A European Comparison." European Sociological Review 29(2):155-167.

Larsen, Christian Albrekt. 2008. "The Institutional Logic of Welfare Attitudes: How Welfare Regimes Influence Public Support." Comparative Political Studies 41(2):145-168.

Lavers, Tom. 2019. "Social Protection in an Aspiring 'Developmental State': The Political Drivers of Ethiopia's PSNP." African Affairs pp. 1-26. 
Mettler, Suzanne. 2005. Soldiers to Citizens: The G.I. Bill and the Making of the Greatest Generation. Oxford, UK: Oxford University Press.

Moene, Karl Ove and Michael Wallerstein. 2003. Targeting and Political Support for Welfare Spending. In Conflict and Governance, ed. Amihai Glazer and Kai A. Konrad. Berlin, Germany: Springer-Verlag.

Ndegwa, Stephen N. 1997. "Citizenship and Ethnicity: An Examination of Two Transition Moments in Kenyan Politics." American Political Science Review 91(3):599-616.

Opalo, Ken Ochieng'. 2019. Legislative Development in Africa: Politics and Post-Colonial Legacies. Cambridge, UK: Cambridge University Press.

Opalo, Ken Ochieng'. 2020. "Constrained Presidential Power in Africa? Legislative Independence and Executive Rule Making in Kenya, 1963-2013." British Journal of Political Science 50(4):1341-1358.

Ouma, Marion. 2020. "Social Protection Policymaking in Kenya: Power and Resistance in a Globalised World." Africa Development 45(2):125-142.

Pavanello, Sara, Carol Watson, W. Onyango-Ouma and Paul Bukuluki. 2016. "Effects of Cash Transfers on Community Interaction: Emerging Evidence." Journal of Development Studies 52(8):1147-1161.

Plagerson, Sophie, Leila Patel, Tessa Hochfeld and Marianne S. Ulriksen. 2019. "Social Policy in South Africa: Navigating the Route to Social Development." World Development 113:19 .

Porisky, Alesha. 2020. "The Distributive Politics of Social Transfers in Kenya." ESID Working Paper No. 155 .

Prifti, Ervin, Silvio Daidone and Benjamin Davis. 2019. "Causal pathways of the productive impacts of cash transfers: Experimental evidence from Lesotho." World Development 115:258-268.

Rothstein, Bo. 2001. "The Universal Welfre State as a Social Dilemma." Rationality and Society 13(2):213-233.

Rudolph, Thomas J. and Jillian Evans. 2005. "Political Trust, Ideology, and Public Support for Government Spending." American Journal of Political Science 49(3):660-671.

Schuring, Esther. 2014. "Preferences for Community-based Targeting - Field Experimental Evidence from Zambia." World Development 54:360-373.

Seekings, Jeremy. 2002. "The Broader Importance of Welfare Reform in South Africa." Social Dynamics 28(2):1-38.

Sharp, Kay, Taylor Brown and Amdissa Teshome. 2006. "Targeting Ethiopia's Productive Safety Net Programme (PSNP)." the IDL group pp. 1-110. 
Stasavage, David and Robin Harding. 2014. "What Democracy Does (and Doesn't Do) for Basic Services: School Fees, School Inputs, and African Elections." Journal of Politics $76(1): 229-245$.

Stone, Diane. 2012. "Transfer and Translation of Policy." Policy Studies 33(6):483-499.

Torkelson, Erin. 2020. "Collateral damages: Cash transfer and debt transfer in South Africa." World Development 126:1-11.

Wanyama, Fredrick O. and Anna McCord. 2017. "The Politics of Scaling up Social Protection in Kenya." WIDER Working Paper pp. 1-30.

World Bank. 2018. The State of Social Safety Nets. Washington, DC: World Bank Group. 


\section{Appendix: The Politics of Social Protection in Kenya}

May 3, 2021

\section{A Public Opinion Survey on Cash Transfers in Kenya}

\section{A.1 Survey Questions}

A key motivation of this research project was to understand public opinion on cash transfers in Kenya, a site of numerous studies of the economic impact of cash transfers. In this section I provide descriptions of the main variables of interest in this paper. IPSOS conducted the survey, comprising a naturally-representative sample of 2015 respondents, between July 25 and August 2, 2018. As part of the survey, I submitted specific questions relating to cash transfers and respondents' partisanship. After completing the survey, IPSOS provided me with fully anonymized survey results, including basic demographic features of respondents. Below are the specific wordings of the questions.

IPSOS is a reputable firm that conducts regular surveys in Kenya. Researchers can propose questions during survey rounds and purchase the data afterwards. IPSOS provides data in anonymized form, with no possibility of knowing the identity of the respondents. IPSOS chooses its own nationally representative sample and runs the surveys. Purchasers of the data receive the results in electronic form already coded.

Q14: For each of the following positions, please tell me which political party the candidate your voted for [in 2017] belongs to:
a. President
b. Member of Parliament
c. Member of County Assembly
d. Governor
e. Senator

Q15: Recently, the government has begun a program to transfer cash to poor Kenyans through mobile phones. In your opinion, which of the following groups of people deserve the most to receive this kind of government assistance? SINGLE RESPONSE - READ OUT
a. Orphans
b. The Unemployed
c. The elderly
d. The disabled
e. None of the above (DO NOT READ)
d. Not sure (DO NOT READ)

Q16: Would you support an increase in VAT taxes on general goods in order to enable the 
government to support groups of people through cash transfer programs via mobile phones?
(a) YES
(b) NO
(c) Not Sure

Q17: Which of the following statements do you agree with the most: (READ OUT)

a) The government should raise taxes on everyone by increasing the prices of items like sugar, unga (flour), and salt, in order to help groups of people in need through cash transfer programs via mobile phones.

b) The government should increase taxes only on the very rich people in order to help those in need through cash transfers programs via mobile phones.

c) Agree with neither (DO NOT READ)

Q18: What do you think is the main reason why some people in Kenya are very poor? (SINGLE RESPONSE - DO NOT READ)
a) Bad luck
b) Laziness
c) Lack of jobs
d) Lack of government assistance
e) Corruption in government
f) Low intelligence
g) Other (specify)
h) Not Sure

\section{A.2 Key Variables of Interest}

This section provides further information and summaries of key variables of interest. Table A1 below presents the summary statistics for the main variables of interest in the analyses. Religion, deservingness, and perceived causes of poverty are specified as factor variables in the all the analysis. Levels of education and income are specified as continuous variables. However, the results are the same even when these variables are operationalized as dichotomous variables (primary vs post-primary) and (KES 10,000 and higher).

It is plausible that religious affiliation is correlated with ideas about redistribution and deservingness among particular vulnerable groups. For that reason, I include in my analyses controls for religious affiliation. It is important to note that this variable merely captures religious affiliation and not the degree of religiosity per se. Figures A1 and A2 provide summaries of religious affiliation in general and by partisanship (reported voting choice in 2017). Although the general distributions look similar overall, the data reveals some variation 
A1: Summary statistics

\begin{tabular}{lccccc}
\hline \multicolumn{1}{c}{ Variable } & Mean & Std. Dev. & Min. & Max. & N \\
\hline Age & 34.209 & 12.95 & 18 & 86 & 2015 \\
Female & 0.509 & 0.5 & 0 & 1 & 2015 \\
Education & 4.316 & 1.884 & 1 & 10 & 2006 \\
Single & 0.287 & 0.453 & 0 & 1 & 2015 \\
Urban & 0.35 & 0.477 & 0 & 1 & 2015 \\
Wage Income & 0.173 & 0.379 & 0 & 1 & 2015 \\
Income & 2.878 & 1.13 & 1 & 14 & 1912 \\
Voted in 2017 & 0.855 & 0.352 & 0 & 1 & 2010 \\
Pro-Incumbent & 0.492 & 0.5 & 0 & 1 & 2015 \\
Support VAT Increase & 0.296 & 0.457 & 0 & 1 & 2015 \\
Tax Everyone & 0.197 & 0.397 & 0 & 1 & 2015 \\
Catholic & 0.238 & 0.426 & 0 & 1 & 2015 \\
Mainline Protestant & 0.403 & 0.491 & 0 & 1 & 2015 \\
Muslim & 0.086 & 0.28 & 0 & 1 & 2015 \\
Other Christian & 0.188 & 0.391 & 0 & 1 & 2015 \\
\hline
\end{tabular}

Figure A1: Respondents' Religious Affiliation

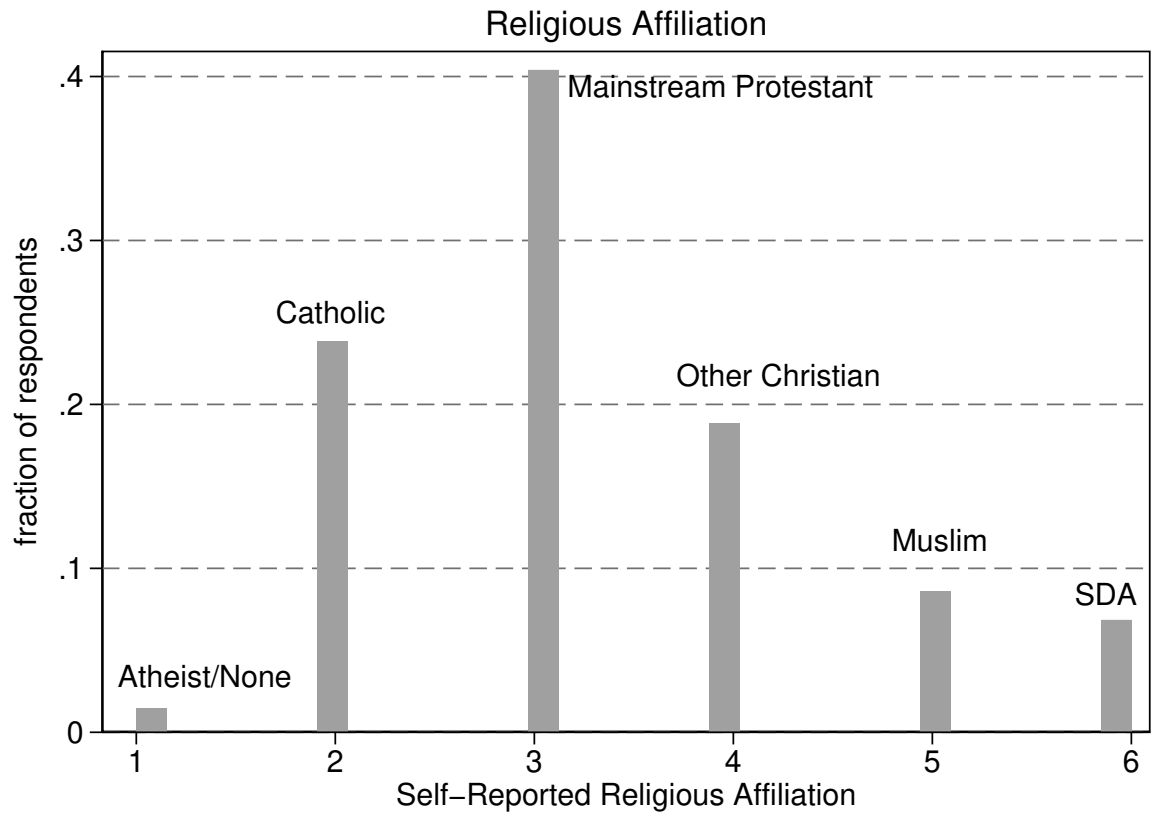

Notes: Figure shows respondents' self-reported religious affiliation. Seventh Day Adventists (SDA) reported as a separate religious identity from other Christians.

on religious affiliation conditional on partisanship - especially with regard to being Catholic or a member of the mainstream protestant churches. Opposition supporters are more likely to be Catholic or to belong to other Christian denominations, while supporters of the incumbent 
Figure A2: Respondents' Religious Affiliation by Partisanship

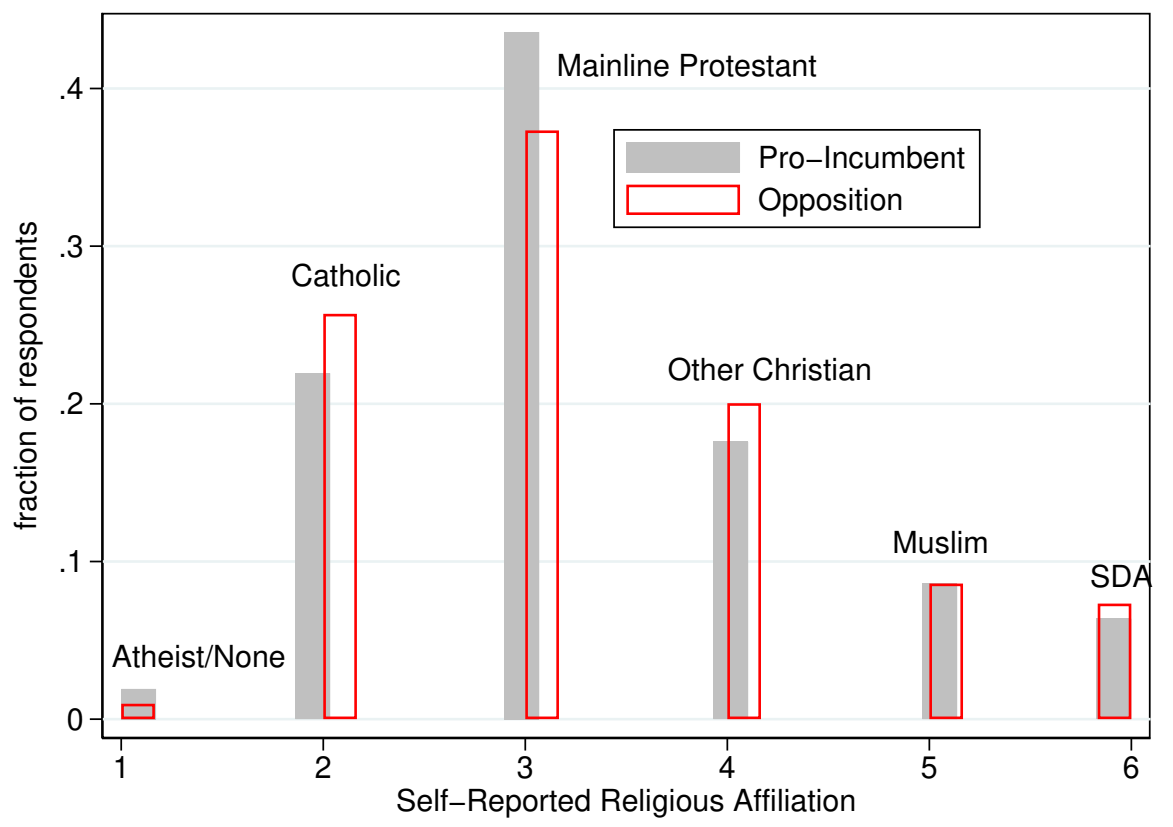

Notes: Figure shows respondents' self-reported religious affiliation. Seventh Day Adventists (SDA) reported as a separate religious identity from other Christians. There is a clear difference in the distribution of religious affiliation conditional on partisanship. In the regression analyses, the correlation between partisanship and attitudes towards taxation remain statistically significant even after controlling for religious affiliation.

Figure A3: Respondents' Religious Affiliation

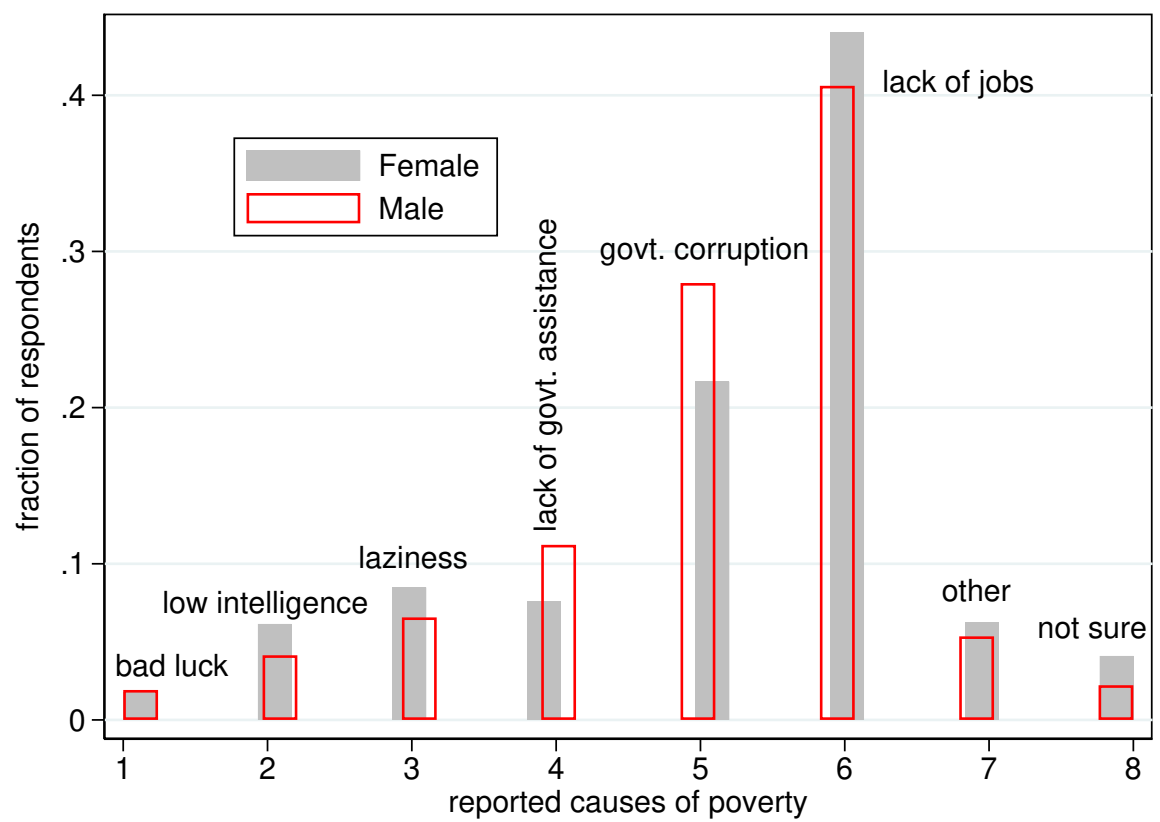

Notes: Figure shows respondents' reported causes of poverty, disaggregated by area of resident (urban and rural). 
Figure A4: Respondents' Religious Affiliation

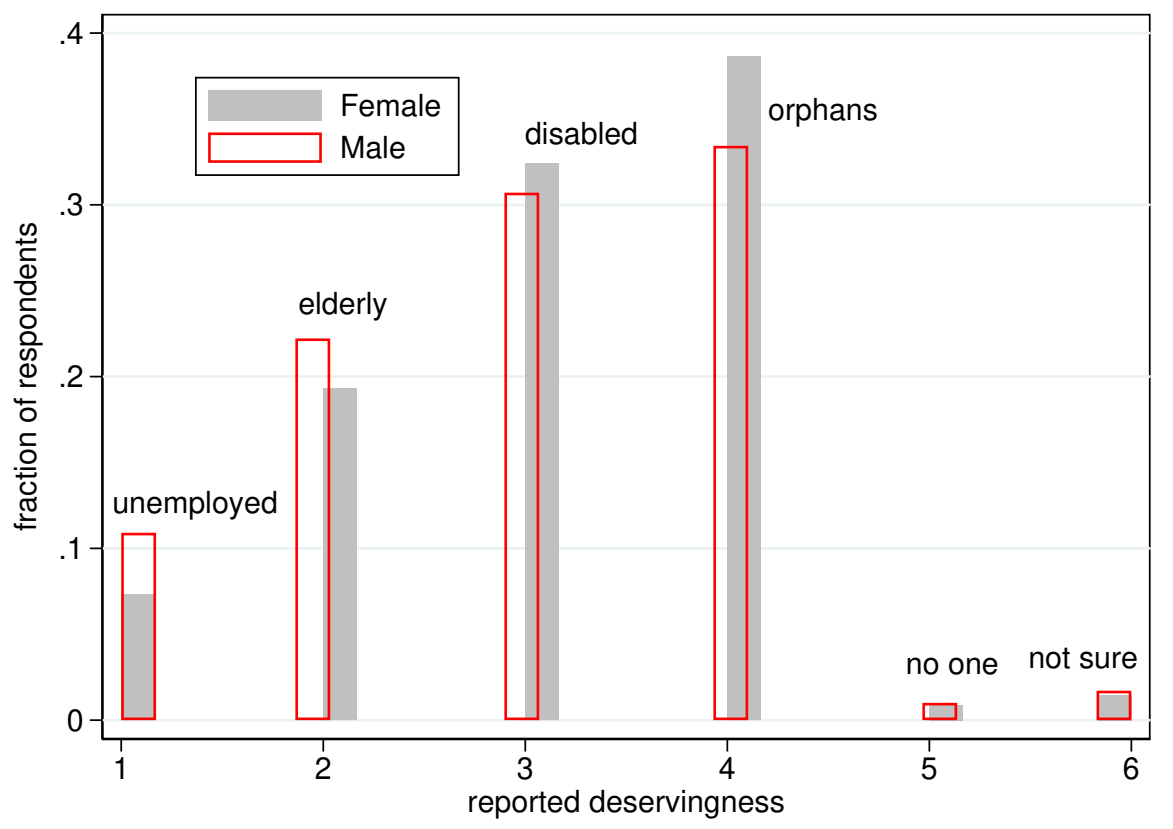

Notes: Figure shows respondents' reported deservingness, disaggregated by area of resident (urban and rural).

Figure A5: Respondents' Religious Affiliation

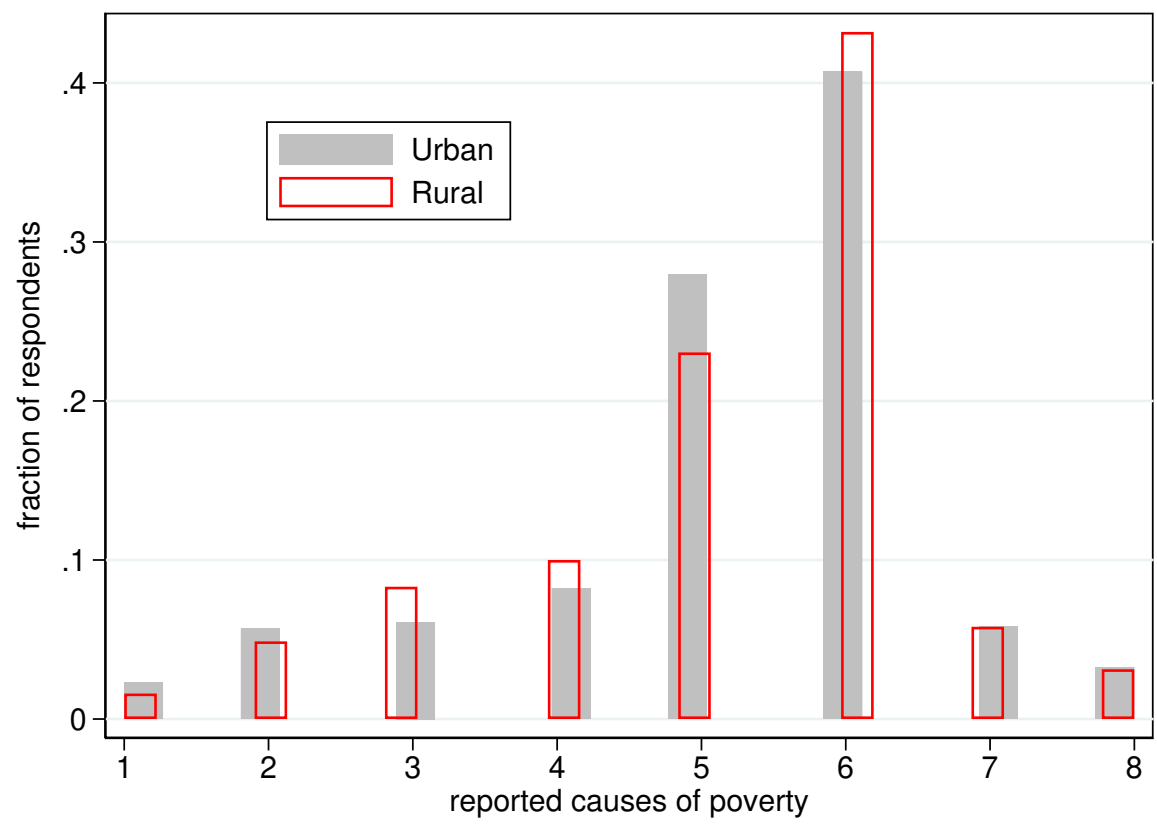

Notes: Figure shows respondents' reported causes of poverty, disaggregated by area of resident (urban and rural).

president are more likely to belong to mainline protestant denominations. The inclusion of this control has no effect on the observed statistical correlation between partisanship and attitudes towards taxation to finance direct cash transfer programs. 
Figure A6: Respondents' Religious Affiliation

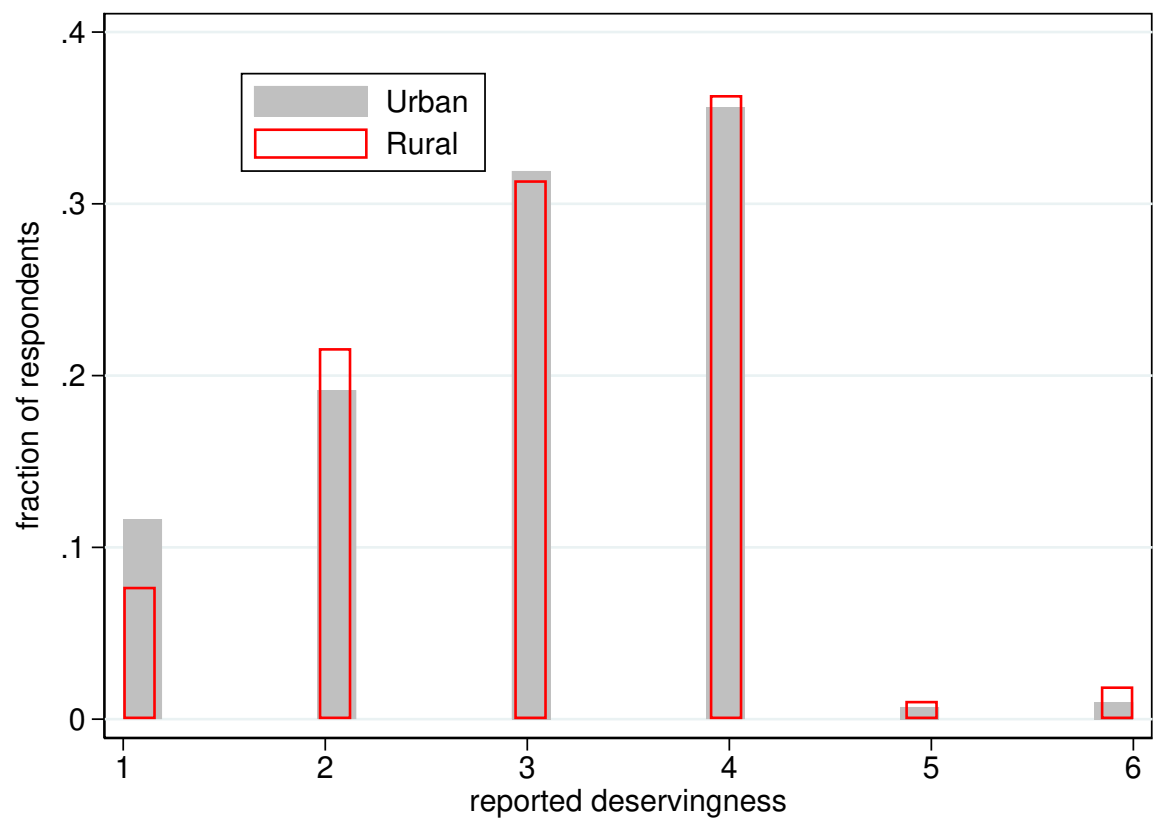

Notes: Figure shows respondents' reported deservingness, disaggregated by area of resident (urban and rural).

Table A2: Main Source of Household Income

\begin{tabular}{lccc}
\hline Activity & Frequency & Percent & Cumulative \\
\hline Self-Employed & 842 & 41.79 & 41.79 \\
Farming & 390 & 19.35 & 61.14 \\
Employed (Private Sector) & 341 & 16.92 & 78.06 \\
Employed (Public Sector) & 149 & 7.39 & 85.46 \\
Private Transfers & 122 & 6.05 & 91.51 \\
Livestock & 59 & 2.93 & 94.44 \\
Refused to Answer & 46 & 2.28 & 96.72 \\
Casual Laborer & 40 & 1.99 & 98.71 \\
Pension & 17 & 0.84 & 99.55 \\
Don't Know & 9 & 0.45 & 100.00 \\
\hline
\end{tabular}

Tables A2 and A3 show the distribution of reported sources of household income and respondents' employment status. Figure A4 shows the distribution of income sources and employment status conditional or reported partisanship. Due to the geographic segregation of economic opportunity and ethnic groups (and therefore partisanship) in Kenya, there are observable differences in the distribution of sources of income and employment status. In the main regression analyses, I use the self-reported employment status as the measure of wage income. The idea is that tax incidence is more salient for individuals who depend on wage income. In the robustness checks below, I also run the same regressions, but with the sensitivity to tax incidence operationalized on the basis of the respondents' households main 
Table A3: Respondents' Reported Employment Status

\begin{tabular}{lccc}
\hline Activity & Frequency & Percent & Cumulative \\
\hline Self Employed & 913 & 45.31 & 45.31 \\
Employed (Private Sector) & 236 & 11.71 & 57.02 \\
Farmer & 231 & 11.46 & 68.49 \\
Unemployed & 228 & 11.32 & 79.80 \\
Casual Laborer & 187 & 9.28 & 89.08 \\
Employed (Public Sector) & 99 & 4.91 & 94.00 \\
Student & 73 & 3.62 & 97.62 \\
Unable to Work & 15 & 0.74 & 98.36 \\
Employed (NGO) & 14 & 0.69 & 99.06 \\
Retired & 11 & 0.55 & 99.60 \\
Refused to Answer & 8 & 0.40 & 100.00 \\
\hline
\end{tabular}

source of income. The results are the same.

Figure A7: Employment Status by Partisanship

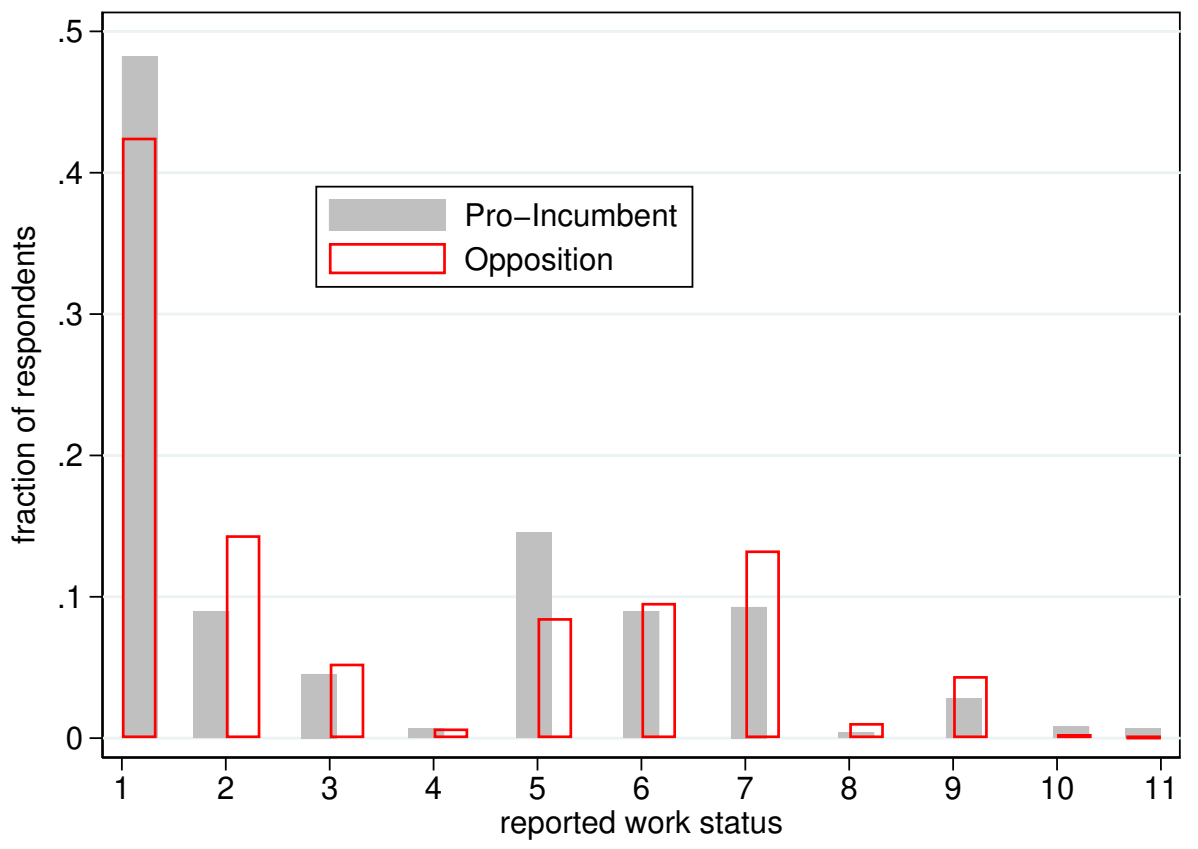

Notes: Figure shows the distribution of respondents' reported employment status. 1: Self-Employed; 2: Employed (Private Sector); 3: Employed (Public Sector); 4: Employed (NGO/Religious Org); 5: Farmer; 6: Casual Laborer; 7: Unemployed; 8: Unable to Work; 9: Student; 10: Retired; 11: Refused to Answer 
Figure A8: Household Income by Partisanship

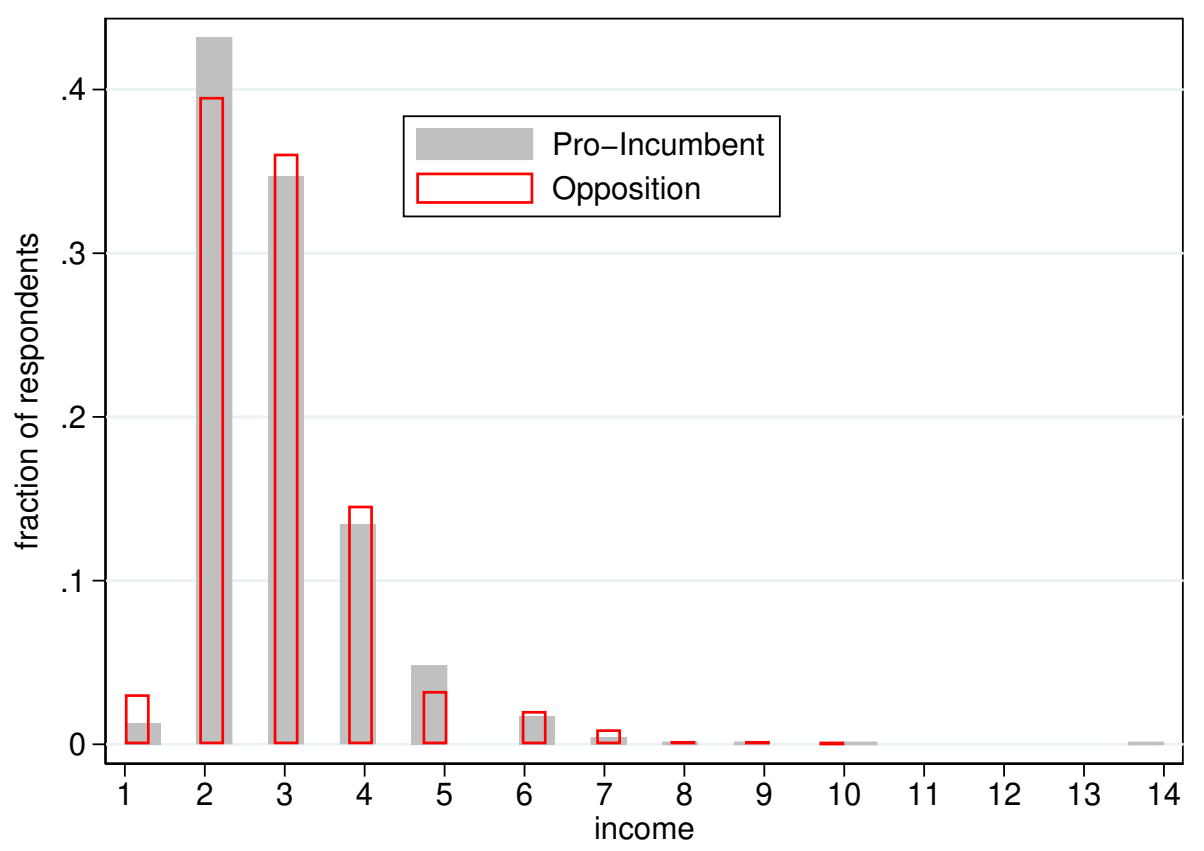

Notes: Figure shows the distribution of respondents at different levels of household income, by partisanship. More than 40 percent of respondents make KES 10,000 or less per month.

\section{A.3 Robustness Checks}

This section presents the same regression analyses presented in the main results using different specifications. OLS regressions and having opposition to increasing VAT and taxation on just the rich as outcome variables yield similar results. The results are shown in Tables A4 - A9 below. 
Table A4: Correlates of Support for Increasing VAT to Finance Cash Transfers

\begin{tabular}{|c|c|c|c|c|c|c|}
\hline DV: VAT Increase & (1) & $(2)$ & $(3)$ & $(4)$ & $(5)$ & (6) \\
\hline Pro-Incumbent & $\begin{array}{c}0.0878^{*} \\
(0.0338)\end{array}$ & $\begin{array}{c}0.0950^{*} \\
(0.0326)\end{array}$ & $\begin{array}{c}0.0901^{*} \\
(0.0294)\end{array}$ & $\begin{array}{c}0.0925^{*} \\
(0.0326)\end{array}$ & $\begin{array}{c}0.0961^{*} \\
(0.0308)\end{array}$ & $\begin{array}{c}0.0893^{*} \\
(0.0277)\end{array}$ \\
\hline Wage Income & $\begin{array}{l}-0.0541 \\
(0.0282)\end{array}$ & $\begin{array}{c}-0.0417 \\
(0.0232)\end{array}$ & $\begin{array}{l}-0.0428 \\
(0.0222)\end{array}$ & $\begin{array}{c}-0.0497 \\
(0.0233)\end{array}$ & $\begin{array}{l}-0.0388 \\
(0.0227)\end{array}$ & $\begin{array}{c}-0.0479 \\
(0.0222)\end{array}$ \\
\hline Age & $\begin{array}{c}-0.0027^{* *} \\
(0.0008)\end{array}$ & $\begin{array}{c}-0.0034^{* *} \\
(0.0009)\end{array}$ & $\begin{array}{c}-0.0031^{* *} \\
(0.0008)\end{array}$ & $\begin{array}{c}-0.0032^{* *} \\
(0.0009)\end{array}$ & $\begin{array}{c}-0.0036^{* *} \\
(0.0008)\end{array}$ & $\begin{array}{c}-0.0030^{* *} \\
(0.0007)\end{array}$ \\
\hline Female & $\begin{array}{c}0.0045 \\
(0.0122)\end{array}$ & $\begin{array}{c}0.0038 \\
(0.0128)\end{array}$ & $\begin{array}{l}-0.0008 \\
(0.0138)\end{array}$ & $\begin{array}{c}-0.0014 \\
(0.0136)\end{array}$ & $\begin{array}{c}0.0016 \\
(0.0129)\end{array}$ & $\begin{array}{c}-0.0078 \\
(0.0153)\end{array}$ \\
\hline Urban & & $\begin{array}{l}-0.0013 \\
(0.0264)\end{array}$ & $\begin{array}{l}-0.0021 \\
(0.0253)\end{array}$ & $\begin{array}{c}0.0023 \\
(0.0260)\end{array}$ & $\begin{array}{l}-0.0000 \\
(0.0283)\end{array}$ & $\begin{array}{c}0.0029 \\
(0.0265)\end{array}$ \\
\hline Education & & $\begin{array}{c}-0.0122 \\
(0.0054)\end{array}$ & $\begin{array}{l}-0.0109 \\
(0.0057)\end{array}$ & $\begin{array}{c}-0.0101 \\
(0.0057)\end{array}$ & $\begin{array}{c}-0.0126^{*} \\
(0.0053)\end{array}$ & $\begin{array}{l}-0.0093 \\
(0.0062)\end{array}$ \\
\hline Income & & -0.0018 & -0.0012 & -0.0021 & -0.0030 & -0.0029 \\
\hline Constant & $\begin{array}{c}0.3536^{* * *} \\
(0.0251)\end{array}$ & $\begin{array}{c}0.4353^{* * *} \\
(0.0637)\end{array}$ & $\begin{array}{c}0.3469^{* * *} \\
(0.0633)\end{array}$ & $\begin{array}{c}0.4751^{* *} \\
(0.1288)\end{array}$ & $\begin{array}{c}0.3547^{* *} \\
(0.0795)\end{array}$ & $\begin{array}{c}0.2858^{*} \\
(0.0971)\end{array}$ \\
\hline Deservingness & $\mathrm{N}$ & $\mathrm{N}$ & $\mathrm{Y}$ & $\mathrm{N}$ & $\mathrm{N}$ & $\mathrm{Y}$ \\
\hline Poverty Cause & $\mathrm{N}$ & $\mathrm{N}$ & $\mathrm{N}$ & $\mathrm{Y}$ & $\mathrm{N}$ & $\mathrm{Y}$ \\
\hline Religion & $\mathrm{N}$ & $\mathrm{N}$ & $\mathrm{N}$ & $\mathrm{N}$ & $\mathrm{Y}$ & $\mathrm{Y}$ \\
\hline$N$ & 2015 & 1904 & 1904 & 1904 & 1902 & 1902 \\
\hline
\end{tabular}

Standard errors in parentheses

${ }^{*} p<0.05,{ }^{* *} p<0.01,{ }^{* * *} p<0.001$

OLS regression with clustered standard errors (Kenya's 8 regions). The dependent variable is respondents' stated support for raising VAT on general consumer goods to finance direct cash transfers. Estimation results include controls for respondents belief in deservingness of recipients (column 3), causes of poverty (column 4), and religion (column 3) and all three (column 6). 
Table A5: Correlates of Support for Increasing VAT to Finance Cash Transfers

\begin{tabular}{|c|c|c|c|c|c|c|}
\hline DV: VAT Increase & (1) & $(2)$ & (3) & (4) & (5) & (6) \\
\hline Pro-Incumbent & $\begin{array}{l}0.0878^{*} \\
(0.0338)\end{array}$ & $\begin{array}{l}0.0878^{*} \\
(0.0333)\end{array}$ & $\begin{array}{l}0.0827^{*} \\
(0.0308)\end{array}$ & $\begin{array}{l}0.0854^{*} \\
(0.0330)\end{array}$ & $\begin{array}{l}0.0883^{*} \\
(0.0316)\end{array}$ & $\begin{array}{l}0.0813^{*} \\
(0.0289)\end{array}$ \\
\hline Wage Income & $\begin{array}{l}-0.0541 \\
(0.0282)\end{array}$ & $\begin{array}{l}-0.0471 \\
(0.0217)\end{array}$ & $\begin{array}{l}-0.0474 \\
(0.0215)\end{array}$ & $\begin{array}{c}-0.0534^{*} \\
(0.0223)\end{array}$ & $\begin{array}{l}-0.0453 \\
(0.0214)\end{array}$ & $\begin{array}{l}-0.0518^{*} \\
(0.0219)\end{array}$ \\
\hline Age & $\begin{array}{c}-0.0027^{* *} \\
(0.0008)\end{array}$ & $\begin{array}{c}-0.0026^{*} \\
(0.0008)\end{array}$ & $\begin{array}{c}-0.0023^{*} \\
(0.0008)\end{array}$ & $\begin{array}{c}-0.0024^{*} \\
(0.0008)\end{array}$ & $\begin{array}{c}-0.0027^{*} \\
(0.0008)\end{array}$ & $\begin{array}{l}-0.0022^{*} \\
(0.0007)\end{array}$ \\
\hline Female & $\begin{array}{c}0.0045 \\
(0.0122)\end{array}$ & $\begin{array}{c}0.0024 \\
(0.0130)\end{array}$ & $\begin{array}{l}-0.0027 \\
(0.0139)\end{array}$ & $\begin{array}{c}-0.0032 \\
(0.0136)\end{array}$ & $\begin{array}{c}0.0011 \\
(0.0134)\end{array}$ & $\begin{array}{c}-0.0091 \\
(0.0149)\end{array}$ \\
\hline Urban & & $\begin{array}{c}0.0015 \\
(0.0263)\end{array}$ & $\begin{array}{c}0.0008 \\
(0.0251)\end{array}$ & $\begin{array}{c}0.0048 \\
(0.0262)\end{array}$ & $\begin{array}{c}0.0043 \\
(0.0279)\end{array}$ & $\begin{array}{c}0.0067 \\
(0.0262)\end{array}$ \\
\hline Post Primary & & $\begin{array}{c}0.0066 \\
(0.0311)\end{array}$ & $\begin{array}{c}0.0092 \\
(0.0309)\end{array}$ & $\begin{array}{c}0.0113 \\
(0.0324)\end{array}$ & $\begin{array}{c}0.0048 \\
(0.0312)\end{array}$ & $\begin{array}{c}0.0116 \\
(0.0322)\end{array}$ \\
\hline Above KES10k & & $\begin{array}{l}-0.0410 \\
(0.0230)\end{array}$ & $\begin{array}{l}-0.0419 \\
(0.0226)\end{array}$ & $\begin{array}{l}-0.0401 \\
(0.0231)\end{array}$ & $\begin{array}{l}-0.0420 \\
(0.0224)\end{array}$ & $\begin{array}{l}-0.0422 \\
(0.0222)\end{array}$ \\
\hline Constant & $\begin{array}{c}0.3536^{* * *} \\
(0.0251)\end{array}$ & $\begin{array}{c}0.3699^{* * *} \\
(0.0583)\end{array}$ & $\begin{array}{c}0.3020^{* *} \\
(0.0574)\end{array}$ & $\begin{array}{c}0.3989^{* *} \\
(0.0930)\end{array}$ & $\begin{array}{c}0.3354^{* *} \\
(0.0629)\end{array}$ & $\begin{array}{c}0.2836^{*} \\
(0.0832)\end{array}$ \\
\hline Deservingness & $\mathrm{N}$ & $\mathrm{N}$ & $\mathrm{Y}$ & $\mathrm{N}$ & $\mathrm{N}$ & $\mathrm{Y}$ \\
\hline Poverty Cause & $\mathrm{N}$ & $\mathrm{N}$ & $\mathrm{N}$ & Y & $\mathrm{N}$ & Y \\
\hline Religion & $\mathrm{N}$ & $\mathrm{N}$ & $\mathrm{N}$ & $\mathrm{N}$ & $\mathrm{Y}$ & $\mathrm{Y}$ \\
\hline$N$ & 2015 & 2015 & 2015 & 2015 & 2012 & 2012 \\
\hline
\end{tabular}

Standard errors in parentheses

${ }^{*} p<0.05,{ }^{* *} p<0.01,{ }^{* * *} p<0.001$

OLS regression with clustered standard errors (Kenya's 8 regions). The dependent variable is respondents' stated support for raising VAT on general consumer goods to finance direct cash transfers. Estimation results include controls for respondents belief in deservingness of recipients (column 3), causes of poverty (column 4), and religion (column 3) and all three (column 6). Education is operationalized as a binary indicator of whether a respondent has any post-primary education. Income is operationalized as a binary indicator of whether respondents report incomes above KES 10,000 
Table A6: Correlates of Support for Taxing Everyone to Finance Cash Transfers

\begin{tabular}{|c|c|c|c|c|c|c|}
\hline DV: Tax Everyone & (1) & (2) & $(3)$ & (4) & (5) & (6) \\
\hline Pro-Incumbent & $\begin{array}{l}0.0434^{* *} \\
(0.0094)\end{array}$ & $\begin{array}{c}0.0403^{* * *} \\
(0.0065)\end{array}$ & $\begin{array}{c}0.0395^{* * *} \\
(0.0063)\end{array}$ & $\begin{array}{c}0.0387^{* * *} \\
(0.0053)\end{array}$ & $\begin{array}{c}0.0400^{* * *} \\
(0.0058)\end{array}$ & $\begin{array}{c}0.0375^{* * *} \\
(0.0052)\end{array}$ \\
\hline Wage Income & $\begin{array}{l}-0.0001 \\
(0.0288)\end{array}$ & $\begin{array}{c}0.0020 \\
(0.0279)\end{array}$ & $\begin{array}{c}0.0025 \\
(0.0277)\end{array}$ & $\begin{array}{l}-0.0011 \\
(0.0281)\end{array}$ & $\begin{array}{c}0.0012 \\
(0.0285)\end{array}$ & $\begin{array}{l}-0.0013 \\
(0.0282)\end{array}$ \\
\hline Age & $\begin{array}{c}-0.0019^{*} \\
(0.0006)\end{array}$ & $\begin{array}{c}-0.0023 \\
(0.0010)\end{array}$ & $\begin{array}{c}-0.0022 \\
(0.0010)\end{array}$ & $\begin{array}{c}-0.0022 \\
(0.0011)\end{array}$ & $\begin{array}{c}-0.0023 \\
(0.0010)\end{array}$ & $\begin{array}{c}-0.0021 \\
(0.0010)\end{array}$ \\
\hline Female & $\begin{array}{l}0.0267^{*} \\
(0.0100)\end{array}$ & $\begin{array}{c}0.0241 \\
(0.0138)\end{array}$ & $\begin{array}{c}0.0225 \\
(0.0139)\end{array}$ & $\begin{array}{c}0.0197 \\
(0.0144)\end{array}$ & $\begin{array}{c}0.0250 \\
(0.0127)\end{array}$ & $\begin{array}{c}0.0192 \\
(0.0133)\end{array}$ \\
\hline Urban & & $\begin{array}{l}-0.0330 \\
(0.0321)\end{array}$ & $\begin{array}{l}-0.0331 \\
(0.0309)\end{array}$ & $\begin{array}{l}-0.0306 \\
(0.0327)\end{array}$ & $\begin{array}{l}-0.0324 \\
(0.0306)\end{array}$ & $\begin{array}{c}-0.0302 \\
(0.0298)\end{array}$ \\
\hline Education & & $\begin{array}{l}-0.0046 \\
(0.0097)\end{array}$ & $\begin{array}{l}-0.0043 \\
(0.0092)\end{array}$ & $\begin{array}{l}-0.0041 \\
(0.0097)\end{array}$ & $\begin{array}{l}-0.0045 \\
(0.0094)\end{array}$ & $\begin{array}{l}-0.0037 \\
(0.0091)\end{array}$ \\
\hline Income & & $\begin{array}{l}-0.0022 \\
(0.0126)\end{array}$ & $\begin{array}{l}-0.0022 \\
(0.0125)\end{array}$ & $\begin{array}{l}-0.0020 \\
(0.0127)\end{array}$ & $\begin{array}{l}-0.0021 \\
(0.0128)\end{array}$ & $\begin{array}{l}-0.0019 \\
(0.0128)\end{array}$ \\
\hline Constant & $\begin{array}{l}0.2265^{* *} \\
(0.0420)\end{array}$ & $\begin{array}{l}0.2808^{*} \\
(0.0908)\end{array}$ & $\begin{array}{l}0.2551^{* *} \\
(0.0477)\end{array}$ & $\begin{array}{l}0.3330^{*} \\
(0.1042)\end{array}$ & $\begin{array}{c}0.3171 \\
(0.1387)\end{array}$ & $\begin{array}{l}0.3473^{*} \\
(0.1186)\end{array}$ \\
\hline Deservingness & $\mathrm{N}$ & $\mathrm{N}$ & $\mathrm{Y}$ & $\mathrm{N}$ & $\mathrm{N}$ & $\mathrm{Y}$ \\
\hline Poverty Cause & $\mathrm{N}$ & $\mathrm{N}$ & $\mathrm{N}$ & $\mathrm{Y}$ & $\mathrm{N}$ & $\mathrm{Y}$ \\
\hline Religion & $\mathrm{N}$ & $\mathrm{N}$ & $\mathrm{N}$ & $\mathrm{N}$ & $\mathrm{Y}$ & $\mathrm{Y}$ \\
\hline$N$ & 2015 & 1904 & 1904 & 1904 & 1902 & 1902 \\
\hline
\end{tabular}

Standard errors in parentheses

${ }^{*} p<0.05,{ }^{* *} p<0.01,{ }^{* * *} p<0.001$

OLS regression with clustered standard errors (Kenya's 8 regions). The dependent variable is respondents' stated support for raising VAT on everyone to finance direct cash transfers. Estimation results include controls for respondents belief in deservingness of recipients (column 3), causes of poverty (column 4), and religion (column 3) and all three (column 6). 
Table A7: Correlates of Support for Taxing Everyone to Finance Cash Transfers

\begin{tabular}{|c|c|c|c|c|c|c|}
\hline DV: Tax Everyone & $(1)$ & $(2)$ & $(3)$ & (4) & $(5)$ & $(6)$ \\
\hline Pro-Incumbent & $\begin{array}{l}0.0434^{* *} \\
(0.0094)\end{array}$ & $\begin{array}{c}0.0400^{* * *} \\
(0.0064)\end{array}$ & $\begin{array}{c}0.0396^{* * *} \\
(0.0055)\end{array}$ & $\begin{array}{c}0.0389^{* * *} \\
(0.0050)\end{array}$ & $\begin{array}{c}0.0386^{* * *} \\
(0.0055)\end{array}$ & $\begin{array}{c}0.0375^{* * *} \\
(0.0038)\end{array}$ \\
\hline Wage Income & $\begin{array}{l}-0.0001 \\
(0.0288)\end{array}$ & $\begin{array}{c}0.0086 \\
(0.0268)\end{array}$ & $\begin{array}{c}0.0091 \\
(0.0265)\end{array}$ & $\begin{array}{c}0.0066 \\
(0.0274)\end{array}$ & $\begin{array}{c}0.0078 \\
(0.0272)\end{array}$ & $\begin{array}{c}0.0066 \\
(0.0273)\end{array}$ \\
\hline Age & $\begin{array}{c}-0.0019^{*} \\
(0.0006)\end{array}$ & $\begin{array}{l}-0.0020 \\
(0.0010)\end{array}$ & $\begin{array}{l}-0.0019 \\
(0.0009)\end{array}$ & $\begin{array}{l}-0.0019 \\
(0.0010)\end{array}$ & $\begin{array}{l}-0.0020 \\
(0.0009)\end{array}$ & $\begin{array}{c}-0.0018 \\
(0.0009)\end{array}$ \\
\hline Female & $\begin{array}{l}0.0267^{*} \\
(0.0100)\end{array}$ & $\begin{array}{c}0.0260 \\
(0.0114)\end{array}$ & $\begin{array}{c}0.0243 \\
(0.0115)\end{array}$ & $\begin{array}{c}0.0224 \\
(0.0121)\end{array}$ & $\begin{array}{l}0.0269^{*} \\
(0.0106)\end{array}$ & $\begin{array}{c}0.0216 \\
(0.0109)\end{array}$ \\
\hline Urban & & $\begin{array}{l}-0.0252 \\
(0.0299)\end{array}$ & $\begin{array}{l}-0.0247 \\
(0.0289)\end{array}$ & $\begin{array}{l}-0.0229 \\
(0.0305)\end{array}$ & $\begin{array}{c}-0.0233 \\
(0.0273)\end{array}$ & $\begin{array}{l}-0.0201 \\
(0.0269)\end{array}$ \\
\hline Post Primary & & $\begin{array}{c}0.0045 \\
(0.0345)\end{array}$ & $\begin{array}{c}0.0046 \\
(0.0336)\end{array}$ & $\begin{array}{c}0.0046 \\
(0.0342)\end{array}$ & $\begin{array}{c}0.0038 \\
(0.0329)\end{array}$ & $\begin{array}{c}0.0039 \\
(0.0319)\end{array}$ \\
\hline Above KES10k & & $\begin{array}{l}-0.0271 \\
(0.0262)\end{array}$ & $\begin{array}{l}-0.0276 \\
(0.0262)\end{array}$ & $\begin{array}{l}-0.0261 \\
(0.0266)\end{array}$ & $\begin{array}{l}-0.0265 \\
(0.0273)\end{array}$ & $\begin{array}{l}-0.0262 \\
(0.0278)\end{array}$ \\
\hline Constant & $\begin{array}{c}0.2265^{* *} \\
(0.0420) \\
(0.0420)\end{array}$ & $\begin{array}{c}0.2514^{*} \\
(0.0759) \\
(0.0908)\end{array}$ & $\begin{array}{c}0.2288^{* * *} \\
(0.0401) \\
(0.0477)\end{array}$ & $\begin{array}{c}0.3179^{* *} \\
(0.0896) \\
(0.1042)\end{array}$ & $\begin{array}{c}0.2912 \\
(0.1319) \\
(0.1387)\end{array}$ & $\begin{array}{c}0.3204^{*} \\
(0.1278) \\
(0.1186)\end{array}$ \\
\hline Deservingness & $\mathrm{N}$ & $\mathrm{N}$ & $\mathrm{Y}$ & $\mathrm{N}$ & $\mathrm{N}$ & $\mathrm{Y}$ \\
\hline Poverty Cause & $\mathrm{N}$ & $\mathrm{N}$ & $\mathrm{N}$ & $\mathrm{Y}$ & $\mathrm{N}$ & $\mathrm{Y}$ \\
\hline Religion & $\mathrm{N}$ & $\mathrm{N}$ & $\mathrm{N}$ & $\mathrm{N}$ & $\mathrm{Y}$ & $\mathrm{Y}$ \\
\hline$N$ & 2015 & 2015 & 2015 & 2015 & 2012 & 2012 \\
\hline
\end{tabular}

Standard errors in parentheses

${ }^{*} p<0.05,{ }^{* *} p<0.01,{ }^{* * *} p<0.001$

OLS regression with clustered standard errors (Kenya's 8 regions). The dependent variable is respondents' stated support for raising VAT on everyone to finance direct cash transfers. Estimation results include controls for respondents belief in deservingness of recipients (column 3), causes of poverty (column 4), and religion (column 3) and all three (column 6). Education is operationalized as a binary indicator of whether a respondent has any post-primary education. Income is operationalized as a binary indicator of whether respondents report incomes above KES 10,000 
Table A8: Correlates of Opposition to Increasing VAT to Finance Cash Transfers

\begin{tabular}{|c|c|c|c|c|c|c|}
\hline DV: Tax Everyone & (1) & $(2)$ & $(3)$ & (4) & $(5)$ & $(6)$ \\
\hline Pro-Incumbent & $\begin{array}{c}-0.3724^{*} \\
(0.1752)\end{array}$ & $\begin{array}{c}-0.4155^{*} \\
(0.1722)\end{array}$ & $\begin{array}{c}-0.3962^{*} \\
(0.1591)\end{array}$ & $\begin{array}{c}-0.4031^{*} \\
(0.1732)\end{array}$ & $\begin{array}{c}-0.4243^{*} \\
(0.1670)\end{array}$ & $\begin{array}{c}-0.3933^{*} \\
(0.1534)\end{array}$ \\
\hline Wage Income & $\begin{array}{c}0.2374 \\
(0.1220)\end{array}$ & $\begin{array}{c}0.1517 \\
(0.0976)\end{array}$ & $\begin{array}{c}0.1571 \\
(0.0913)\end{array}$ & $\begin{array}{l}0.1923^{*} \\
(0.0960)\end{array}$ & $\begin{array}{c}0.1355 \\
(0.0945)\end{array}$ & $\begin{array}{c}0.1835^{*} \\
(0.0868)\end{array}$ \\
\hline Age & $\begin{array}{l}0.0129^{* *} \\
(0.0049)\end{array}$ & $\begin{array}{l}0.0164^{* *} \\
(0.0051)\end{array}$ & $\begin{array}{l}0.0150^{* *} \\
(0.0047)\end{array}$ & $\begin{array}{l}0.0154^{* *} \\
(0.0050)\end{array}$ & $\begin{array}{c}0.0167^{* * *} \\
(0.0047)\end{array}$ & $\begin{array}{c}0.0144^{* *} \\
(0.0044)\end{array}$ \\
\hline Female & $\begin{array}{l}-0.0230 \\
(0.0658)\end{array}$ & $\begin{array}{l}-0.0207 \\
(0.0634)\end{array}$ & $\begin{array}{l}-0.0012 \\
(0.0702)\end{array}$ & $\begin{array}{c}0.0015 \\
(0.0667)\end{array}$ & $\begin{array}{l}-0.0182 \\
(0.0633)\end{array}$ & $\begin{array}{c}0.0236 \\
(0.0765)\end{array}$ \\
\hline Urban & & $\begin{array}{l}-0.0536 \\
(0.1299)\end{array}$ & $\begin{array}{l}-0.0507 \\
(0.1285)\end{array}$ & $\begin{array}{l}-0.0713 \\
(0.1308)\end{array}$ & $\begin{array}{l}-0.0534 \\
(0.1370)\end{array}$ & $\begin{array}{c}-0.0664 \\
(0.1347)\end{array}$ \\
\hline Education & & $\begin{array}{l}0.0687^{*} \\
(0.0281)\end{array}$ & $\begin{array}{l}0.0637^{*} \\
(0.0305)\end{array}$ & $\begin{array}{c}0.0577 \\
(0.0315)\end{array}$ & $\begin{array}{c}0.0700^{* *} \\
(0.0268)\end{array}$ & $\begin{array}{c}0.0541 \\
(0.0337)\end{array}$ \\
\hline Income & & $\begin{array}{c}0.0411 \\
(0.0353)\end{array}$ & $\begin{array}{c}0.0387 \\
(0.0356)\end{array}$ & $\begin{array}{c}0.0419 \\
(0.0352)\end{array}$ & $\begin{array}{c}0.0494 \\
(0.0359)\end{array}$ & $\begin{array}{c}0.0487 \\
(0.0360)\end{array}$ \\
\hline Constant & $\begin{array}{c}0.4898^{* * *} \\
(0.1002)\end{array}$ & $\begin{array}{l}-0.0065 \\
(0.2508)\end{array}$ & $\begin{array}{c}0.3910 \\
(0.2878)\end{array}$ & $\begin{array}{c}-0.1912 \\
(0.5063)\end{array}$ & $\begin{array}{c}0.2918 \\
(0.4030)\end{array}$ & $\begin{array}{c}0.5965 \\
(0.3848)\end{array}$ \\
\hline Deservingness & $\mathrm{N}$ & $\mathrm{N}$ & $\mathrm{Y}$ & $\mathrm{N}$ & $\mathrm{N}$ & $\mathrm{Y}$ \\
\hline Poverty Cause & $\mathrm{N}$ & $\mathrm{N}$ & $\mathrm{N}$ & $\mathrm{Y}$ & $\mathrm{N}$ & $\mathrm{Y}$ \\
\hline Religion & $\mathrm{N}$ & $\mathrm{N}$ & $\mathrm{N}$ & $\mathrm{N}$ & $\mathrm{Y}$ & $\mathrm{Y}$ \\
\hline$N$ & 2015 & 1904 & 1886 & 1904 & 1902 & 1884 \\
\hline
\end{tabular}

Standard errors in parentheses

${ }^{*} p<0.05,{ }^{* *} p<0.01,{ }^{* * *} p<0.001$

Logistic regression with clustered standard errors (Kenya's 8 regions). The dependent variable is respondents' stated opposition to raising VAT to finance direct cash transfers. Estimation results include controls for respondents belief in deservingness of recipients (column 3), causes of poverty (column 4), and religion (column 3) and all three (column 6). 
Table A9: Correlates of Support for Taxing Only the Rich to Finance Cash Transfers

\begin{tabular}{|c|c|c|c|c|c|c|}
\hline DV: VAT Increase & $(1)$ & $(2)$ & $(3)$ & $(4)$ & $(5)$ & $(6)$ \\
\hline Pro-Incumbent & $\begin{array}{c}-0.2534^{* * *} \\
(0.0376)\end{array}$ & $\begin{array}{c}-0.2247^{* * *} \\
(0.0322)\end{array}$ & $\begin{array}{c}-0.2340^{* * *} \\
(0.0371)\end{array}$ & $\begin{array}{c}-0.2278^{* * *} \\
(0.0372)\end{array}$ & $\begin{array}{c}-0.2197^{* * *} \\
(0.0331)\end{array}$ & $\begin{array}{c}-0.2356^{* * *} \\
(0.0364)\end{array}$ \\
\hline Wage Income & $\begin{array}{c}0.0490 \\
(0.1367)\end{array}$ & $\begin{array}{c}-0.0272 \\
(0.1482)\end{array}$ & $\begin{array}{l}-0.0184 \\
(0.1598)\end{array}$ & $\begin{array}{l}-0.0092 \\
(0.1551)\end{array}$ & $\begin{array}{l}-0.0174 \\
(0.1487)\end{array}$ & $\begin{array}{c}0.0076 \\
(0.1681)\end{array}$ \\
\hline Age & $\begin{array}{c}0.0039 \\
(0.0028)\end{array}$ & $\begin{array}{c}0.0050 \\
(0.0039)\end{array}$ & $\begin{array}{c}0.0056 \\
(0.0040)\end{array}$ & $\begin{array}{c}0.0045 \\
(0.0041)\end{array}$ & $\begin{array}{c}0.0052 \\
(0.0040)\end{array}$ & $\begin{array}{c}0.0054 \\
(0.0043)\end{array}$ \\
\hline Female & $\begin{array}{c}-0.1132 \\
(0.0819)\end{array}$ & $\begin{array}{c}-0.1434 \\
(0.0768)\end{array}$ & $\begin{array}{c}-0.1385 \\
(0.0823)\end{array}$ & $\begin{array}{c}-0.1216 \\
(0.0734)\end{array}$ & $\begin{array}{c}-0.1369^{*} \\
(0.0693)\end{array}$ & $\begin{array}{c}-0.1093 \\
(0.0760)\end{array}$ \\
\hline Urban & & $\begin{array}{c}0.2373 \\
(0.1241)\end{array}$ & $\begin{array}{c}0.2219 \\
(0.1207)\end{array}$ & $\begin{array}{c}0.2099 \\
(0.1289)\end{array}$ & $\begin{array}{c}0.2444 \\
(0.1272)\end{array}$ & $\begin{array}{c}0.1991 \\
(0.1263)\end{array}$ \\
\hline Education & & $\begin{array}{c}0.0184 \\
(0.0281)\end{array}$ & $\begin{array}{c}0.0186 \\
(0.0268)\end{array}$ & $\begin{array}{c}0.0179 \\
(0.0273)\end{array}$ & $\begin{array}{c}0.0202 \\
(0.0301)\end{array}$ & $\begin{array}{c}0.0200 \\
(0.0288)\end{array}$ \\
\hline Income & & $\begin{array}{c}0.1074 \\
(0.0644)\end{array}$ & $\begin{array}{c}0.1103 \\
(0.0625)\end{array}$ & $\begin{array}{c}0.1067 \\
(0.0667)\end{array}$ & $\begin{array}{c}0.1003 \\
(0.0655)\end{array}$ & $\begin{array}{c}0.1031 \\
(0.0665)\end{array}$ \\
\hline Constant & $\begin{array}{c}0.5910^{* * *} \\
(0.1321)\end{array}$ & $\begin{array}{c}0.0933 \\
(0.1395)\end{array}$ & $\begin{array}{c}0.2959 \\
(0.1599)\end{array}$ & $\begin{array}{l}-0.1030 \\
(0.3414)\end{array}$ & $\begin{array}{c}0.2120 \\
(0.2211)\end{array}$ & $\begin{array}{c}0.2183 \\
(0.3359)\end{array}$ \\
\hline Deservingness & $\mathrm{N}$ & $\mathrm{N}$ & $\mathrm{Y}$ & $\mathrm{N}$ & $\mathrm{N}$ & $\mathrm{Y}$ \\
\hline Poverty Cause & $\mathrm{N}$ & $\mathrm{N}$ & $\mathrm{N}$ & $\mathrm{Y}$ & $\mathrm{N}$ & $\mathrm{Y}$ \\
\hline Religion & $\mathrm{N}$ & $\mathrm{N}$ & $\mathrm{N}$ & $\mathrm{N}$ & $\mathrm{Y}$ & $\mathrm{Y}$ \\
\hline$N$ & 2015 & 1904 & 1904 & 1904 & 1902 & 1902 \\
\hline
\end{tabular}

Standard errors in parentheses

${ }^{*} p<0.05,{ }^{* *} p<0.01,{ }^{* * *} p<0.001$

Logistic regression with clustered standard errors (Kenya's 8 regions). The dependent variable is respondents' support for taxing only the rich to finance cash transfers. Results include controls for respondents belief in deservingness of recipients (column 3), causes of poverty (column 4), and religion (column 3) and all three (column 6). 
Table A10: Correlates of Opposition to Increasing VAT to Finance Cash Transfers

\begin{tabular}{|c|c|c|c|c|c|c|}
\hline DV: VAT Increase & (1) & $(2)$ & $(3)$ & $(4)$ & $(5)$ & (6) \\
\hline Pro-Incumbent & $\begin{array}{l}0.4300^{*} \\
(0.1690)\end{array}$ & $\begin{array}{c}0.4654^{* *} \\
(0.1629)\end{array}$ & $\begin{array}{c}0.4460^{* *} \\
(0.1485)\end{array}$ & $\begin{array}{c}0.4578^{* *} \\
(0.1625)\end{array}$ & $\begin{array}{c}0.4685^{* *} \\
(0.1557)\end{array}$ & $\begin{array}{c}0.4425^{* *} \\
(0.1391)\end{array}$ \\
\hline Wage Income & $\begin{array}{c}-0.2731^{*} \\
(0.1386)\end{array}$ & $\begin{array}{l}-0.2132 \\
(0.1159)\end{array}$ & $\begin{array}{l}-0.2199 \\
(0.1135)\end{array}$ & $\begin{array}{c}-0.2565^{*} \\
(0.1164)\end{array}$ & $\begin{array}{l}-0.1991 \\
(0.1130)\end{array}$ & $\begin{array}{c}-0.2495^{*} \\
(0.1141)\end{array}$ \\
\hline Age & $\begin{array}{c}-0.0138^{* *} \\
(0.0043)\end{array}$ & $\begin{array}{c}-0.0175^{* * *} \\
(0.0047)\end{array}$ & $\begin{array}{c}-0.0161^{* * *} \\
(0.0043)\end{array}$ & $\begin{array}{c}-0.0164^{* * *} \\
(0.0046)\end{array}$ & $\begin{array}{c}-0.0180^{* * *} \\
(0.0043)\end{array}$ & $\begin{array}{c}-0.0154^{* * *} \\
(0.0039)\end{array}$ \\
\hline Female & $\begin{array}{c}0.0193 \\
(0.0610)\end{array}$ & $\begin{array}{c}0.0158 \\
(0.0626)\end{array}$ & $\begin{array}{l}-0.0053 \\
(0.0689)\end{array}$ & $\begin{array}{c}-0.0080 \\
(0.0670)\end{array}$ & $\begin{array}{c}0.0069 \\
(0.0621)\end{array}$ & $\begin{array}{c}-0.0383 \\
(0.0759)\end{array}$ \\
\hline ASAL & $\begin{array}{c}0.0917 \\
(0.1191)\end{array}$ & $\begin{array}{c}0.1501 \\
(0.1152)\end{array}$ & $\begin{array}{c}0.1300 \\
(0.1108)\end{array}$ & $\begin{array}{c}0.1730 \\
(0.1169)\end{array}$ & $\begin{array}{c}0.0298 \\
(0.1517)\end{array}$ & $\begin{array}{c}0.0304 \\
(0.1506)\end{array}$ \\
\hline Urban & & $\begin{array}{l}-0.0141 \\
(0.1335)\end{array}$ & $\begin{array}{l}-0.0137 \\
(0.1296)\end{array}$ & $\begin{array}{c}0.0004 \\
(0.1334)\end{array}$ & $\begin{array}{l}-0.0014 \\
(0.1405)\end{array}$ & $\begin{array}{c}0.0114 \\
(0.1335)\end{array}$ \\
\hline Education & & $\begin{array}{c}-0.0605^{*} \\
(0.0256)\end{array}$ & $\begin{array}{c}-0.0548^{*} \\
(0.0273)\end{array}$ & $\begin{array}{l}-0.0503 \\
(0.0274)\end{array}$ & $\begin{array}{c}-0.0633^{* *} \\
(0.0240)\end{array}$ & $\begin{array}{l}-0.0476 \\
(0.0295)\end{array}$ \\
\hline Income & & $\begin{array}{l}-0.0114 \\
(0.0288)\end{array}$ & $\begin{array}{l}-0.0092 \\
(0.0274)\end{array}$ & $\begin{array}{l}-0.0130 \\
(0.0280)\end{array}$ & $\begin{array}{l}-0.0160 \\
(0.0271)\end{array}$ & $\begin{array}{l}-0.0158 \\
(0.0238)\end{array}$ \\
\hline Constant & $\begin{array}{c}-0.5948^{* * *} \\
(0.1220)\end{array}$ & $\begin{array}{l}-0.1831 \\
(0.2902)\end{array}$ & $\begin{array}{c}-0.6321^{*} \\
(0.3218)\end{array}$ & $\begin{array}{l}-0.0311 \\
(0.5435)\end{array}$ & $\begin{array}{l}-0.5667 \\
(0.4080)\end{array}$ & $\begin{array}{c}-0.9479^{*} \\
(0.4536)\end{array}$ \\
\hline Deservingness & $\mathrm{N}$ & $\mathrm{N}$ & $\mathrm{Y}$ & $\mathrm{N}$ & $\mathrm{N}$ & $\mathrm{Y}$ \\
\hline Poverty Cause & $\mathrm{N}$ & $\mathrm{N}$ & $\mathrm{N}$ & $\mathrm{Y}$ & $\mathrm{N}$ & $\mathrm{Y}$ \\
\hline Religion & $\mathrm{N}$ & $\mathrm{N}$ & $\mathrm{N}$ & $\mathrm{N}$ & $\mathrm{Y}$ & $\mathrm{Y}$ \\
\hline$N$ & 2015 & 1904 & 1886 & 1904 & 1902 & 1884 \\
\hline
\end{tabular}

Standard errors in parentheses

${ }^{*} p<0.05,{ }^{* *} p<0.01,{ }^{* * *} p<0.001$

Logistic regression with clustered standard errors (Kenya's 8 regions). The dependent variable is respondents' stated opposition to raising VAT to finance direct cash transfers. Estimation results include controls for respondents belief in deservingness of recipients (column 3), causes of poverty (column 4), and religion (column 3) and all three (column $6)$. 
Table A11: Correlates of Support for Taxing Only the Rich to Finance Cash Transfers

\begin{tabular}{|c|c|c|c|c|c|c|}
\hline DV: VAT Increase & (1) & $(2)$ & $(3)$ & $(4)$ & $(5)$ & (6) \\
\hline Pro-Incumbent & $\begin{array}{c}0.2759^{* * *} \\
(0.0409)\end{array}$ & $\begin{array}{c}0.2641^{* * *} \\
(0.0348)\end{array}$ & $\begin{array}{c}0.2585^{* * *} \\
(0.0381)\end{array}$ & $\begin{array}{c}0.2565^{* * *} \\
(0.0328)\end{array}$ & $\begin{array}{c}0.2642^{* * *} \\
(0.0293)\end{array}$ & $\begin{array}{c}0.2509^{* * *} \\
(0.0358)\end{array}$ \\
\hline Wage Income & $\begin{array}{l}-0.0005 \\
(0.1840)\end{array}$ & $\begin{array}{c}0.0149 \\
(0.1821)\end{array}$ & $\begin{array}{c}0.0182 \\
(0.1806)\end{array}$ & $\begin{array}{c}-0.0059 \\
(0.1817)\end{array}$ & $\begin{array}{c}0.0065 \\
(0.1845)\end{array}$ & $\begin{array}{c}-0.0123 \\
(0.1831)\end{array}$ \\
\hline Age & $\begin{array}{c}-0.0129^{* * *} \\
(0.0039)\end{array}$ & $\begin{array}{c}-0.0156^{* *} \\
(0.0059)\end{array}$ & $\begin{array}{c}-0.0148^{* *} \\
(0.0056)\end{array}$ & $\begin{array}{c}-0.0149^{*} \\
(0.0060)\end{array}$ & $\begin{array}{c}-0.0158^{* *} \\
(0.0055)\end{array}$ & $\begin{array}{c}-0.0141^{* *} \\
(0.0053)\end{array}$ \\
\hline Female & $\begin{array}{c}0.1730^{* *} \\
(0.0623)\end{array}$ & $\begin{array}{c}0.1525 \\
(0.0885)\end{array}$ & $\begin{array}{c}0.1425 \\
(0.0889)\end{array}$ & $\begin{array}{c}0.1266 \\
(0.0924)\end{array}$ & $\begin{array}{c}0.1573^{*} \\
(0.0796)\end{array}$ & $\begin{array}{c}0.1243 \\
(0.0838)\end{array}$ \\
\hline ASAL & $\begin{array}{l}-0.1065 \\
(0.1965)\end{array}$ & $\begin{array}{c}0.1549 \\
(0.1924)\end{array}$ & $\begin{array}{c}0.1535 \\
(0.1919)\end{array}$ & $\begin{array}{c}0.1540 \\
(0.1977)\end{array}$ & $\begin{array}{c}0.2998 \\
(0.2074)\end{array}$ & $\begin{array}{c}0.2759 \\
(0.2132)\end{array}$ \\
\hline Urban & & $\begin{array}{l}-0.2240 \\
(0.1960)\end{array}$ & $\begin{array}{l}-0.2237 \\
(0.1910)\end{array}$ & $\begin{array}{l}-0.2121 \\
(0.2030)\end{array}$ & $\begin{array}{l}-0.2262 \\
(0.1787)\end{array}$ & $\begin{array}{l}-0.2133 \\
(0.1807)\end{array}$ \\
\hline Education & & $\begin{array}{l}-0.0304 \\
(0.0623)\end{array}$ & $\begin{array}{l}-0.0284 \\
(0.0595)\end{array}$ & $\begin{array}{l}-0.0268 \\
(0.0626)\end{array}$ & $\begin{array}{l}-0.0314 \\
(0.0583)\end{array}$ & $\begin{array}{l}-0.0257 \\
(0.0567)\end{array}$ \\
\hline Income & & $\begin{array}{l}-0.0163 \\
(0.0854)\end{array}$ & $\begin{array}{l}-0.0163 \\
(0.0847)\end{array}$ & $\begin{array}{l}-0.0145 \\
(0.0863)\end{array}$ & $\begin{array}{l}-0.0127 \\
(0.0850)\end{array}$ & $\begin{array}{l}-0.0108 \\
(0.0856)\end{array}$ \\
\hline Constant & $\begin{array}{c}-1.1931^{* * *} \\
(0.2689)\end{array}$ & $\begin{array}{l}-0.8640 \\
(0.5620)\end{array}$ & $\begin{array}{c}-1.0333^{* * *} \\
(0.2724)\end{array}$ & $\begin{array}{c}-0.5818 \\
(0.6152)\end{array}$ & $\begin{array}{l}-0.6567 \\
(0.7909)\end{array}$ & $\begin{array}{l}-0.4919 \\
(0.5903)\end{array}$ \\
\hline Deservingness & $\mathrm{N}$ & $\mathrm{N}$ & $\mathrm{Y}$ & $\mathrm{N}$ & $\mathrm{N}$ & $\mathrm{Y}$ \\
\hline Poverty Cause & $\mathrm{N}$ & $\mathrm{N}$ & $\mathrm{N}$ & $\mathrm{Y}$ & $\mathrm{N}$ & Y \\
\hline Religion & $\mathrm{N}$ & $\mathrm{N}$ & $\mathrm{N}$ & $\mathrm{N}$ & $\mathrm{Y}$ & $\mathrm{Y}$ \\
\hline$N$ & 2015 & 1904 & 1904 & 1904 & 1902 & 1902 \\
\hline
\end{tabular}

Standard errors in parentheses

${ }^{*} p<0.05,{ }^{* *} p<0.01,{ }^{* * *} p<0.001$

Logistic regression with clustered standard errors (Kenya's 8 regions). The dependent variable is respondents' support for taxing only the rich to finance cash transfers. Results include controls for respondents belief in deservingness of recipients (column 3), causes of poverty (column 4), and religion (column 3) and all three (column $6)$. 
Figure A9: Predictive Margins: Opposition to Increasing VAT
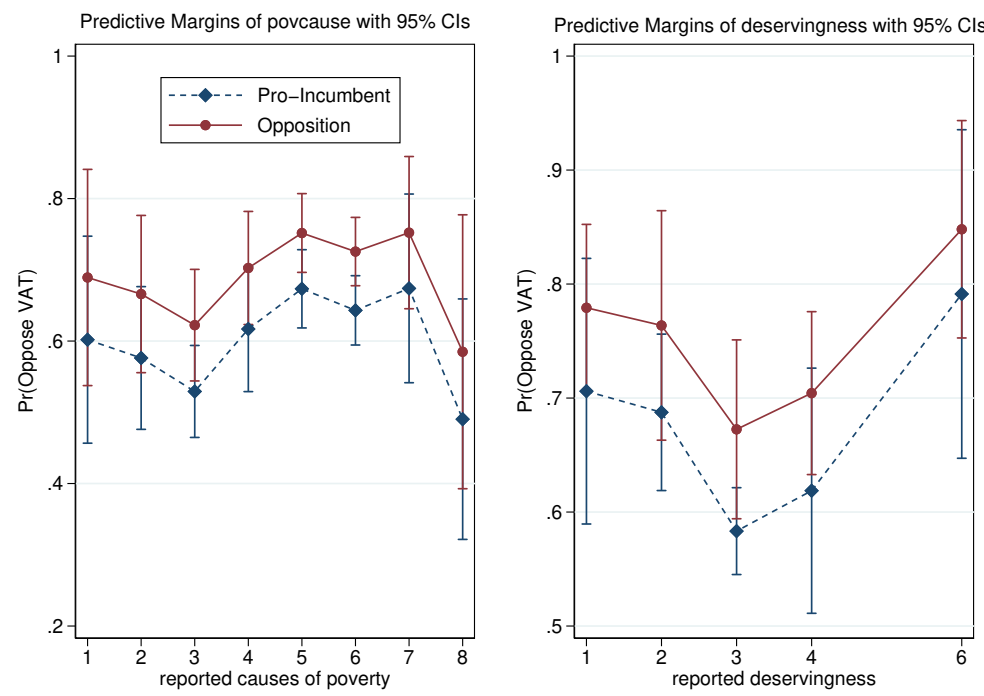

Notes: Graphs show predictive margins at different views on the causes of poverty (left) and deservingness (right), with opposition to increasing VAT as the outcome. Supporters of the incumbent president are consistently less likely to oppose increasing VAT to finance cash transfers.

Figure A10: Predictive Margins: Taxing Only the Rich
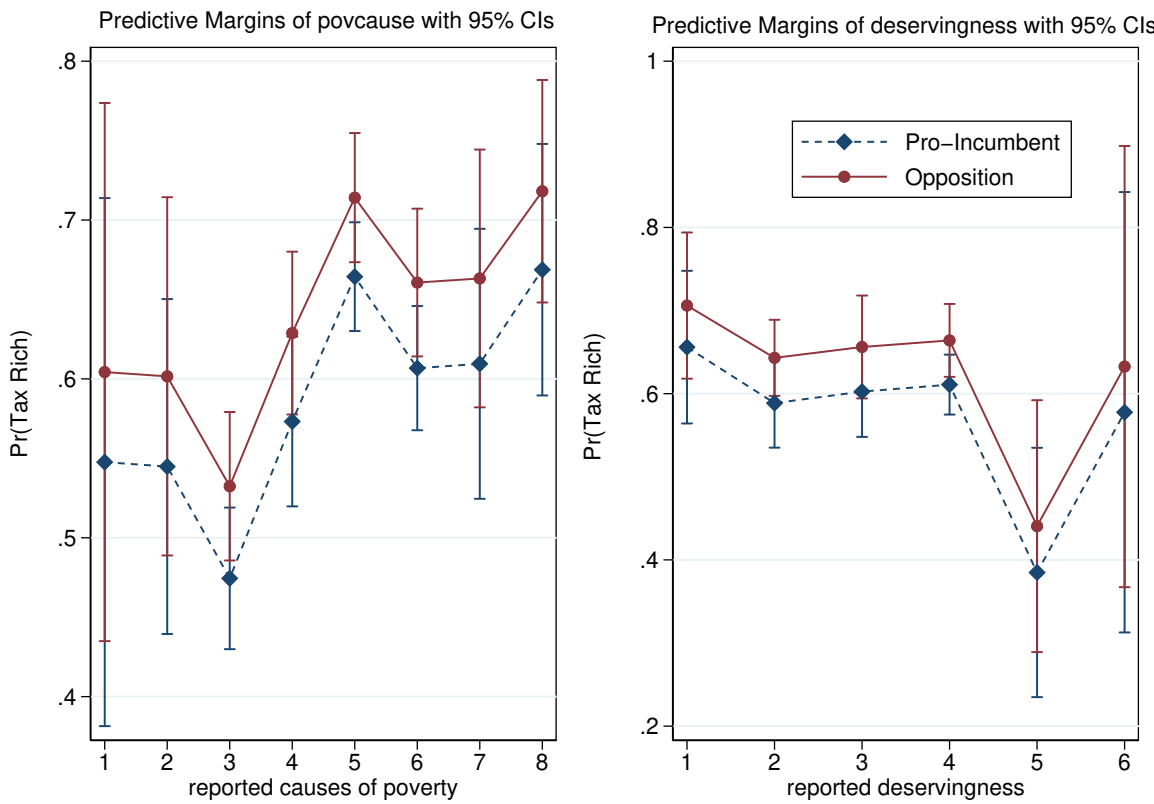

Notes: Graphs show predictive margins at different views on the causes of poverty (left) and deservingness (right), with opinion on only taxing the rich as the outcome. Supporters of the incumbent president are consistently more likely to oppose only taxing the rich to finance cash transfers. 


\section{Main Text Tables and Figures}

Table 1: Kenya's Social Protection Sector (2017)

\begin{tabular}{|c|c|c|c|}
\hline Category & Program & $\begin{array}{l}\text { Beneficiary } \\
\text { Households }\end{array}$ & Funding Source \\
\hline \multirow[t]{15}{*}{ Social Assistance } & 1) Orphans and Vulnerable Children & 365,232 & $\begin{array}{l}\text { GoK, UNICEF, DFID, } \\
\text { and World Bank }\end{array}$ \\
\hline & 2) Older Persons Cash Transfer Program & 320,636 & GoK \\
\hline & 3) Hunger Safety Net Program (HSNP) & 101,630 & DFID \\
\hline & 4) People with Severe Disabilities & 41,374 & GoK \\
\hline & 5) Cash for Assets & 60,068 & $\begin{array}{l}\text { World Food Program } \\
\text { and GoK }\end{array}$ \\
\hline & 6) Urban Food Subsidy Program & & \\
\hline & 7) Food for Assets & 54,362 & Several Donors \\
\hline & 8) General Food Distribution & 78,000 & GoK \\
\hline & 9) School Feeding Programs & $1,690,000$ & $\begin{array}{l}\text { JICA, DFID, World } \\
\text { Food Program and } \\
\text { GoK }\end{array}$ \\
\hline & 10) HIV/AIDS Nutrition Feeding* & 72,065 & World Food Program \\
\hline & 11) Health Voucher Scheme* & 29,731 people & KFW and GoK \\
\hline & 12) Health Voucher Scheme* (ASAL) & 59,982 people & UNICEF and GoK \\
\hline & 13) Njaa Marufuku (No to Hunger)* & 12,180 groups & GoK \\
\hline & 14) Kazi Kwa Vijana (Workfare for Youth)* & 297,861 people & World Bank and GoK \\
\hline & $\begin{array}{l}\text { 15) National Accelerated Agricultural Input } \\
\text { Access Program* }\end{array}$ & 120,750 & World Bank and GoK \\
\hline \multirow{2}{*}{$\begin{array}{l}\text { Contributory } \\
\text { Schemes }\end{array}$} & 1) National Social Security Fund (NSSF) & & \\
\hline & $\begin{array}{l}\text { 2) Mbao Pension Scheme } \\
\text { 3) Private schemes under the Retirement } \\
\text { Benefits Authority }\end{array}$ & & \\
\hline Health Insurance & National Health Insurance Fund (NHIF) & & \\
\hline
\end{tabular}

Notes: Table shows state of social protection in Kenya as of 2017. Data are from the Kenya National Social Protection Policy (2011) and the Social Protection Sector Review (2017). Figures for the programs with an asterisk $(*)$ are from 2011. 
Table 2: Summary Statistics

\begin{tabular}{lccccc}
\hline \multicolumn{1}{c}{ Variable } & Mean & Std. Dev. & Min. & Max. & N \\
\hline Age & 34.209 & 12.95 & 18 & 86 & 2015 \\
Female & 0.509 & 0.5 & 0 & 1 & 2015 \\
Education & 4.316 & 1.884 & 1 & 10 & 2006 \\
Single & 0.287 & 0.453 & 0 & 1 & 2015 \\
Urban & 0.35 & 0.477 & 0 & 1 & 2015 \\
Wage Income & 0.173 & 0.379 & 0 & 1 & 2015 \\
Income & 2.878 & 1.13 & 1 & 14 & 1912 \\
Voted in 2017 & 0.855 & 0.352 & 0 & 1 & 2010 \\
Voted for Kenyatta $(2017)$ & 0.492 & 0.5 & 0 & 1 & 2015 \\
Support VAT Increase & 0.296 & 0.457 & 0 & 1 & 2015 \\
Tax Everyone & 0.197 & 0.397 & 0 & 1 & 2015 \\
Catholic & 0.238 & 0.426 & 0 & 1 & 2015 \\
Mainline Protestant & 0.403 & 0.491 & 0 & 1 & 2015 \\
Muslim & 0.086 & 0.28 & 0 & 1 & 2015 \\
Other Christian & 0.188 & 0.391 & 0 & 1 & 2015 \\
\hline
\end{tabular}


Table 3: Correlates of Support for Increasing VAT to Finance Cash Transfers

\begin{tabular}{|c|c|c|c|c|c|c|}
\hline DV: VAT Increase & (1) & $(2)$ & $(3)$ & $(4)$ & $(5)$ & $(6)$ \\
\hline Pro-Incumbent & $\begin{array}{l}0.4275^{*} \\
(0.1688)\end{array}$ & $\begin{array}{l}0.4621^{* *} \\
(0.1637)\end{array}$ & $\begin{array}{l}0.4436^{* *} \\
(0.1491)\end{array}$ & $\begin{array}{l}0.4534^{* *} \\
(0.1633)\end{array}$ & $\begin{array}{l}0.4680^{* *} \\
(0.1564)\end{array}$ & $\begin{array}{l}0.4420^{* *} \\
(0.1398)\end{array}$ \\
\hline Wage Income & $\begin{array}{c}-0.2737^{*} \\
(0.1378)\end{array}$ & $\begin{array}{l}-0.2137 \\
(0.1152)\end{array}$ & $\begin{array}{l}-0.2200 \\
(0.1131)\end{array}$ & $\begin{array}{c}-0.2565^{*} \\
(0.1156)\end{array}$ & $\begin{array}{l}-0.1987 \\
(0.1133)\end{array}$ & $\begin{array}{c}-0.2490^{*} \\
(0.1141)\end{array}$ \\
\hline Age & $\begin{array}{c}-0.0138^{* *} \\
(0.0043)\end{array}$ & $\begin{array}{c}-0.0175^{* * *} \\
(0.0047)\end{array}$ & $\begin{array}{c}-0.0161^{* * *} \\
(0.0044)\end{array}$ & $\begin{array}{c}-0.0163^{* * *} \\
(0.0046)\end{array}$ & $\begin{array}{c}-0.0180^{* * *} \\
(0.0044)\end{array}$ & $\begin{array}{c}-0.0154^{* * *} \\
(0.0040)\end{array}$ \\
\hline Female & $\begin{array}{c}0.0215 \\
(0.0588)\end{array}$ & $\begin{array}{c}0.0185 \\
(0.0620)\end{array}$ & $\begin{array}{l}-0.0031 \\
(0.0686)\end{array}$ & $\begin{array}{l}-0.0052 \\
(0.0665)\end{array}$ & $\begin{array}{c}0.0075 \\
(0.0636)\end{array}$ & $\begin{array}{l}-0.0379 \\
(0.0771)\end{array}$ \\
\hline Urban & & $\begin{array}{c}-0.0055 \\
(0.1293)\end{array}$ & $\begin{array}{l}-0.0063 \\
(0.1255)\end{array}$ & $\begin{array}{c}0.0097 \\
(0.1274)\end{array}$ & $\begin{array}{l}-0.0002 \\
(0.1388)\end{array}$ & $\begin{array}{c}0.0126 \\
(0.1306)\end{array}$ \\
\hline Education & & $\begin{array}{l}-0.0610^{*} \\
(0.0254)\end{array}$ & $\begin{array}{c}-0.0553^{*} \\
(0.0272)\end{array}$ & $\begin{array}{l}-0.0510 \\
(0.0271)\end{array}$ & $\begin{array}{c}-0.0633^{* *} \\
(0.0243)\end{array}$ & $\begin{array}{l}-0.0476 \\
(0.0297)\end{array}$ \\
\hline Income & & $\begin{array}{l}-0.0097 \\
(0.0285)\end{array}$ & $\begin{array}{l}-0.0075 \\
(0.0273)\end{array}$ & $\begin{array}{l}-0.0110 \\
(0.0279)\end{array}$ & $\begin{array}{l}-0.0160 \\
(0.0271)\end{array}$ & $\begin{array}{l}-0.0157 \\
(0.0239)\end{array}$ \\
\hline Constant & $\begin{array}{c}-0.5834^{* * *} \\
(0.1130)\end{array}$ & $\begin{array}{c}-0.1739 \\
(0.2881)\end{array}$ & $\begin{array}{l}-0.6278^{*} \\
(0.3198)\end{array}$ & $\begin{array}{l}-0.0022 \\
(0.5755)\end{array}$ & $\begin{array}{l}-0.5655 \\
(0.4015)\end{array}$ & $\begin{array}{c}-0.9467^{*} \\
(0.4505)\end{array}$ \\
\hline Deservingness & $\mathrm{N}$ & $\mathrm{N}$ & $\mathrm{Y}$ & $\mathrm{N}$ & $\mathrm{N}$ & $\mathrm{Y}$ \\
\hline Poverty Cause & $\mathrm{N}$ & $\mathrm{N}$ & $\mathrm{N}$ & $\mathrm{Y}$ & $\mathrm{N}$ & $\mathrm{Y}$ \\
\hline Religion & $\mathrm{N}$ & $\mathrm{N}$ & $\mathrm{N}$ & $\mathrm{N}$ & $\mathrm{Y}$ & $\mathrm{Y}$ \\
\hline$N$ & 2015 & 1904 & 1886 & 1904 & 1902 & 1884 \\
\hline \multicolumn{7}{|c|}{$\begin{array}{l}\text { Standard errors in parentheses } \\
{ }^{*} p<0.05,{ }^{* *} p<0.01,{ }^{* * *} p<0.001\end{array}$} \\
\hline \multicolumn{7}{|c|}{$\begin{array}{l}\text { Logistic regression with clustered standard errors (Kenya's } 8 \text { regions). The dependent variable is respondents' stated } \\
\text { support for increasing VAT on general consumer goods to finance direct cash transfers. Estimation results includ } \\
\text { controls for respondents belief in deservingness of recipients (column 3), causes of poverty (column } 4 \text { ), and religior } \\
\text { (column 3) and all three (column 6). }\end{array}$} \\
\hline
\end{tabular}


Table 4: Correlates of Support for Increasing Consumption Taxes on Everyone

\begin{tabular}{|c|c|c|c|c|c|c|}
\hline DV: Tax Everyone & $(1)$ & $(2)$ & $(3)$ & (4) & $(5)$ & $(6)$ \\
\hline Pro-Incumbent & $\begin{array}{c}0.2784^{* * *} \\
(0.0419)\end{array}$ & $\begin{array}{c}0.2612^{* * *} \\
(0.0419)\end{array}$ & $\begin{array}{c}0.2559^{* * *} \\
(0.0441)\end{array}$ & $\begin{array}{c}0.2530^{* * *} \\
(0.0396)\end{array}$ & $\begin{array}{c}0.2586^{* * *} \\
(0.0384)\end{array}$ & $\begin{array}{c}0.2456^{* * *} \\
(0.0416)\end{array}$ \\
\hline Wage Income & $\begin{array}{c}0.0005 \\
(0.1839)\end{array}$ & $\begin{array}{c}0.0140 \\
(0.1808)\end{array}$ & $\begin{array}{c}0.0176 \\
(0.1796)\end{array}$ & $\begin{array}{l}-0.0064 \\
(0.1808)\end{array}$ & $\begin{array}{c}0.0086 \\
(0.1839)\end{array}$ & $\begin{array}{l}-0.0091 \\
(0.1832)\end{array}$ \\
\hline Age & $\begin{array}{c}-0.0129^{* * *} \\
(0.0039)\end{array}$ & $\begin{array}{c}-0.0156^{* *} \\
(0.0060)\end{array}$ & $\begin{array}{c}-0.0147^{* *} \\
(0.0057)\end{array}$ & $\begin{array}{c}-0.0148^{*} \\
(0.0060)\end{array}$ & $\begin{array}{c}-0.0156^{* *} \\
(0.0058)\end{array}$ & $\begin{array}{l}-0.0140^{*} \\
(0.0055)\end{array}$ \\
\hline Female & $\begin{array}{l}0.1704^{* *} \\
(0.0618)\end{array}$ & $\begin{array}{c}0.1552 \\
(0.0886)\end{array}$ & $\begin{array}{c}0.1451 \\
(0.0892)\end{array}$ & $\begin{array}{c}0.1290 \\
(0.0927)\end{array}$ & $\begin{array}{l}0.1618^{*} \\
(0.0793)\end{array}$ & $\begin{array}{c}0.1271 \\
(0.0842)\end{array}$ \\
\hline Urban & & $\begin{array}{l}-0.2149 \\
(0.2081)\end{array}$ & $\begin{array}{l}-0.2145 \\
(0.2022)\end{array}$ & $\begin{array}{l}-0.2027 \\
(0.2146)\end{array}$ & $\begin{array}{l}-0.2116 \\
(0.1994)\end{array}$ & $\begin{array}{l}-0.1989 \\
(0.1986)\end{array}$ \\
\hline Education & & $\begin{array}{l}-0.0310 \\
(0.0612)\end{array}$ & $\begin{array}{l}-0.0290 \\
(0.0585)\end{array}$ & $\begin{array}{l}-0.0274 \\
(0.0614)\end{array}$ & $\begin{array}{l}-0.0304 \\
(0.0591)\end{array}$ & $\begin{array}{l}-0.0250 \\
(0.0574)\end{array}$ \\
\hline Income & & $\begin{array}{l}-0.0142 \\
(0.0839)\end{array}$ & $\begin{array}{l}-0.0142 \\
(0.0833)\end{array}$ & $\begin{array}{l}-0.0124 \\
(0.0846)\end{array}$ & $\begin{array}{l}-0.0131 \\
(0.0854)\end{array}$ & $\begin{array}{l}-0.0111 \\
(0.0860)\end{array}$ \\
\hline Constant & $\begin{array}{c}-1.2062^{* * *} \\
(0.2539)\end{array}$ & $\begin{array}{l}-0.8539 \\
(0.5488)\end{array}$ & $\begin{array}{c}-1.0278^{* * *} \\
(0.2659)\end{array}$ & $\begin{array}{l}-0.5572 \\
(0.5872)\end{array}$ & $\begin{array}{l}-0.6433 \\
(0.7693)\end{array}$ & $\begin{array}{l}-0.4855 \\
(0.5810)\end{array}$ \\
\hline Deservingness & $\mathrm{N}$ & $\mathrm{N}$ & $\mathrm{Y}$ & $\mathrm{N}$ & $\mathrm{N}$ & $\mathrm{Y}$ \\
\hline Poverty Cause & $\mathrm{N}$ & $\mathrm{N}$ & $\mathrm{N}$ & $\mathrm{Y}$ & $\mathrm{N}$ & $\mathrm{Y}$ \\
\hline Religion & $\mathrm{N}$ & $\mathrm{N}$ & $\mathrm{N}$ & $\mathrm{N}$ & $\mathrm{Y}$ & $\mathrm{Y}$ \\
\hline$N$ & 2015 & 1904 & 1904 & 1904 & 1902 & 1902 \\
\hline \multicolumn{7}{|c|}{$\begin{array}{l}\text { Standard errors in parentheses } \\
{ }^{*} p<0.05,{ }^{* *} p<0.01,{ }^{* * *} p<0.001\end{array}$} \\
\hline $\begin{array}{l}\text { ogistic regression wi } \\
\text { ated support for rais } \\
\text { ansfers. Estimation } \mathrm{r} \\
\text { poverty (column } 4) \text {, }\end{array}$ & $\begin{array}{l}\text { clustered st } \\
\text { VAT on on } \\
\text { lts include cc } \\
\text { d religion (c }\end{array}$ & ard errors & $\begin{array}{l}\text { nya's } 8 \text { regi } \\
\text { osed to the } \\
\text { ents belief ir } \\
\text { hree (colum }\end{array}$ & $\begin{array}{l}\text { The dep } \\
\text { or no tax } \\
\text { ervingness }\end{array}$ & $\begin{array}{l}\text { ent variabl } \\
t \text { all) to fir } \\
\text { ecipients ( }\end{array}$ & $\begin{array}{l}\text { respondents' } \\
\text { e direct cash } \\
\text { mn 3), causes }\end{array}$ \\
\hline
\end{tabular}


Figure 1: Increasing Domestic Investment in Social Protection in Kenya

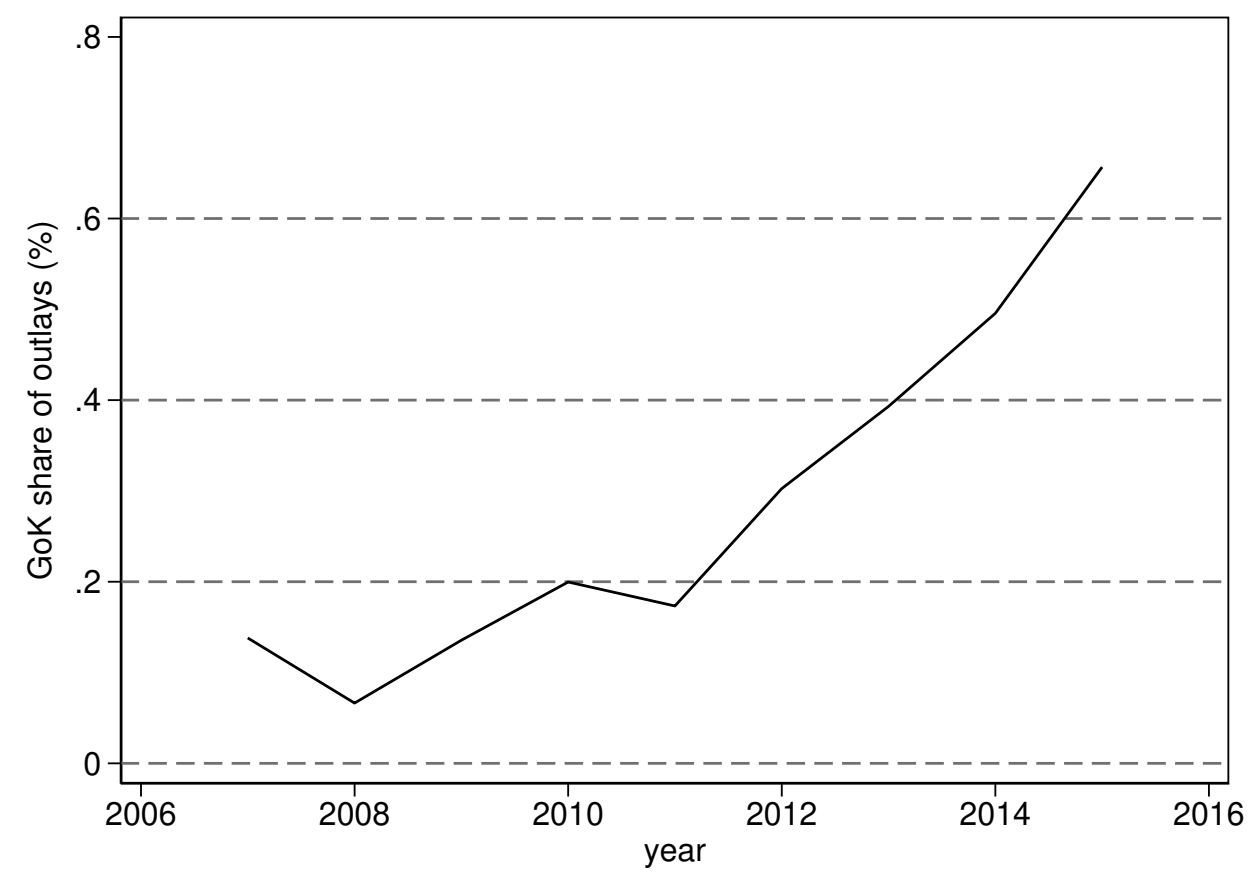

Notes: Graph shows the Kenyan government's increasing share of total outlays towards total protection. Data from the Government of Kenya, Social Protection Sector Review, 2017 (p. 40). 
Figure 2: Partisanship and Reported Causes of Poverty

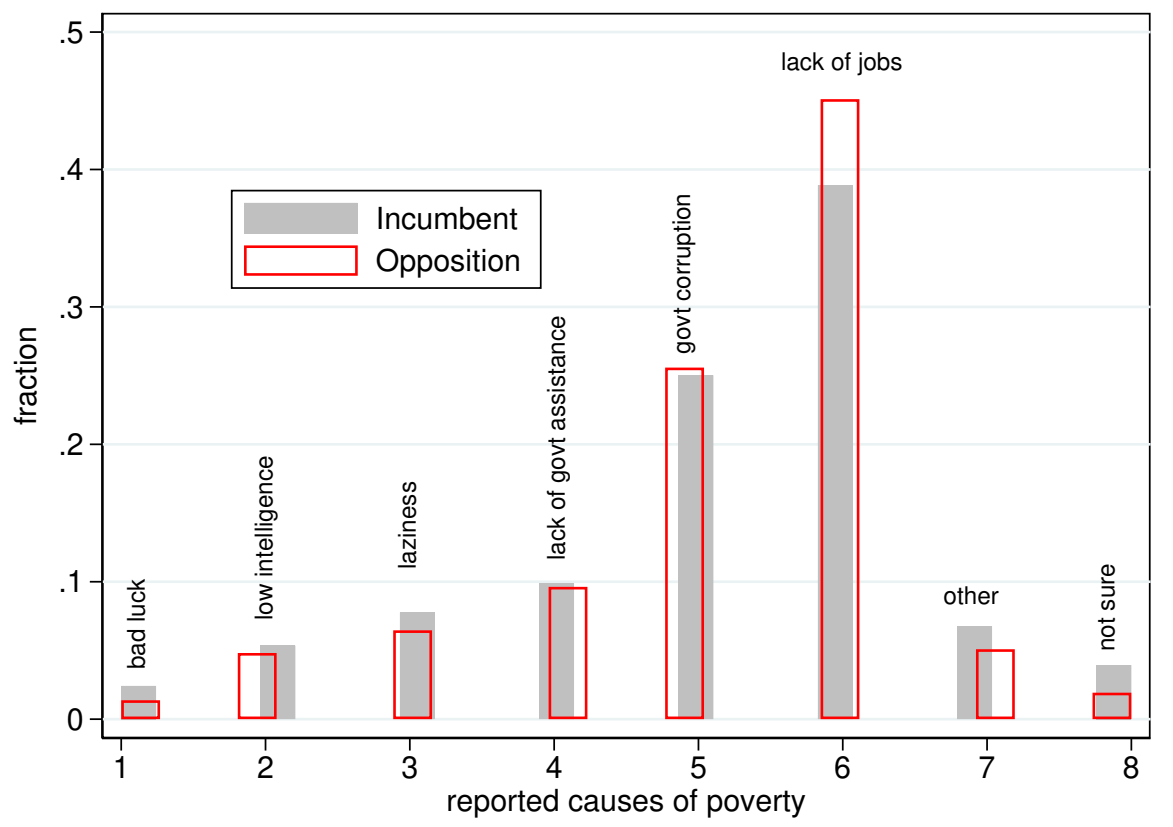

Notes: Figure shows reported cause of poverty among supporters of the incumbent president and the opposition. A lack of jobs and government corruption are the two biggest reported causes of poverty. Opposition supporters are slightly more likely to attribute poverty to a lack of jobs. 
Figure 3: Partisanship and Reported Deservingness

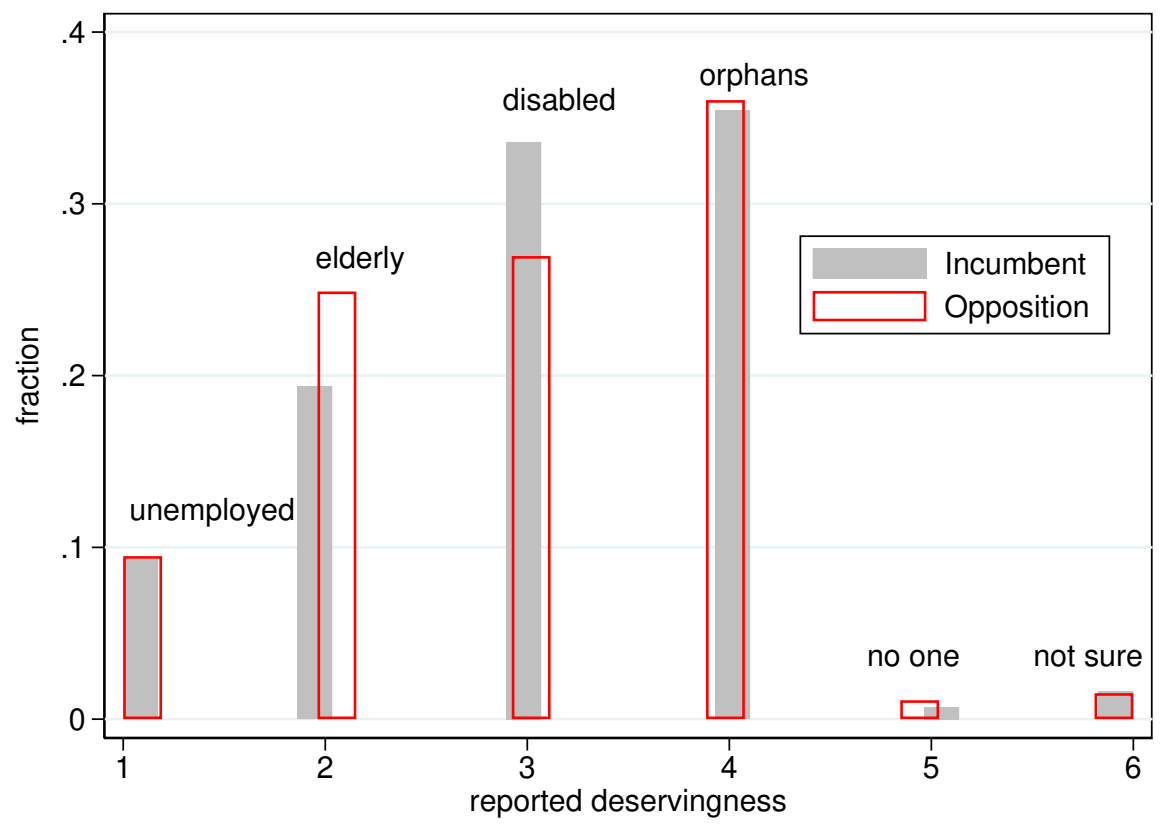

Notes: Figure shows reported deservingness of assistance among supporters of the incumbent president and the opposition. A slight partisan difference exists with regard to the deservingness of the elderly and disabled. 
Figure 4: Reported Causes of Poverty by Partisanship (single response)
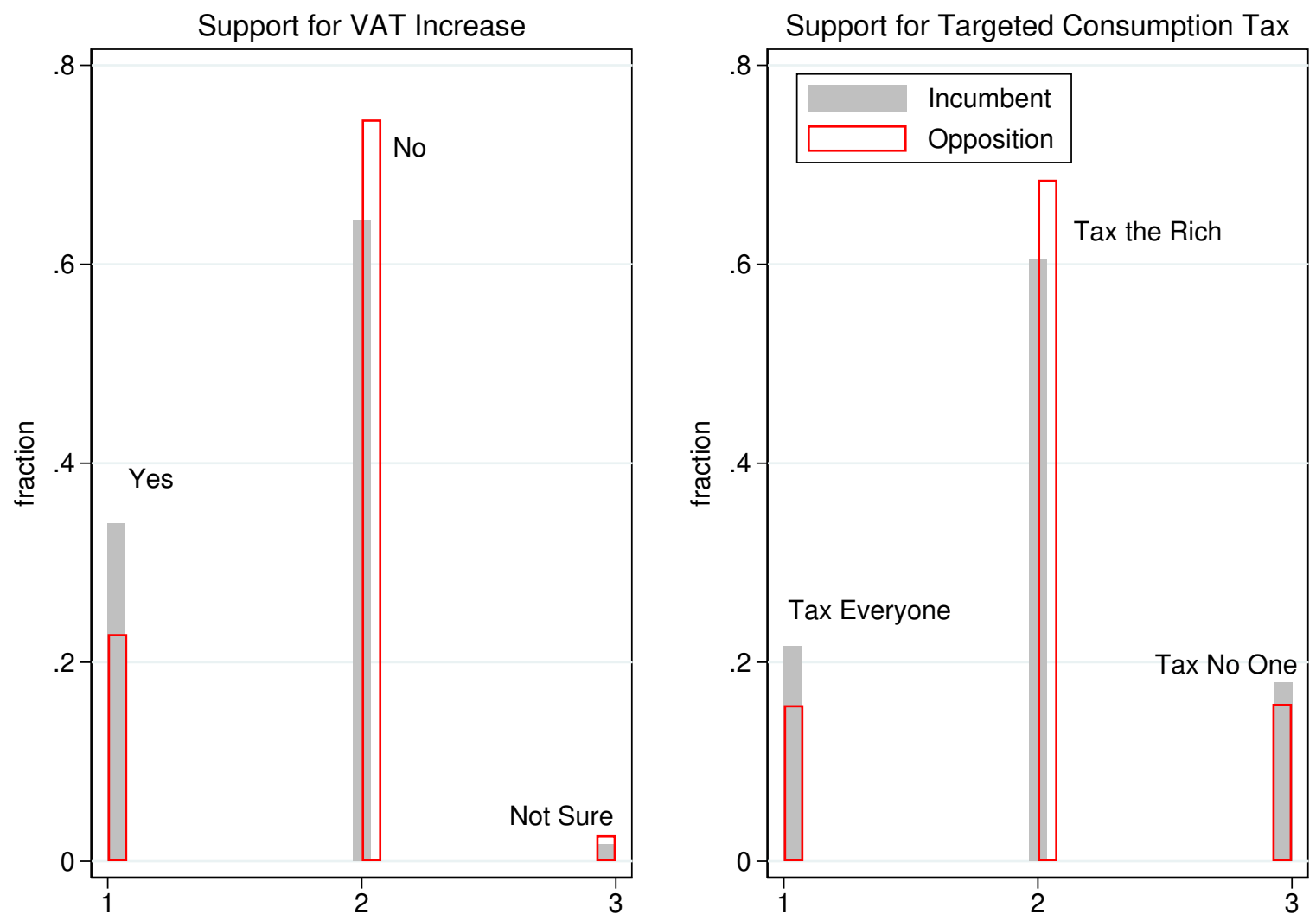

Notes: Figures summarize responses regarding revenue generation to finance cash transfers, split by partisan affiliation. Supporters of the president are more likely to support increasing VAT or taxation of everyone. 
Figure 5: Predictive Margins: Increasing VAT to Finance Cash Transfers
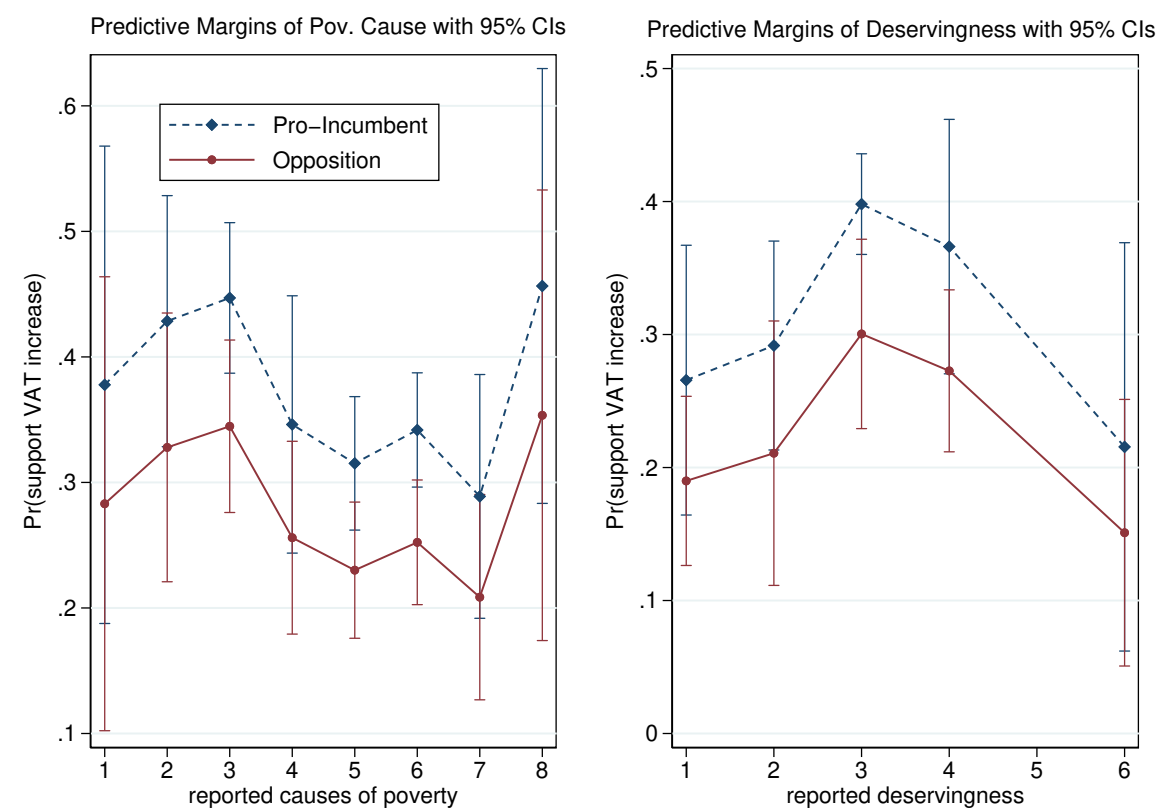

Notes: Graphs show predictive margins at different views on the causes of poverty (left) and deservingness (right), with opinion on increasing VAT as the outcome. Supporters of the incumbent president are consistently more likely to support increasing VAT to finance cash transfers. 
Figure 6: Predictive Margins: Taxing Everyone to Finance Cash Transfers
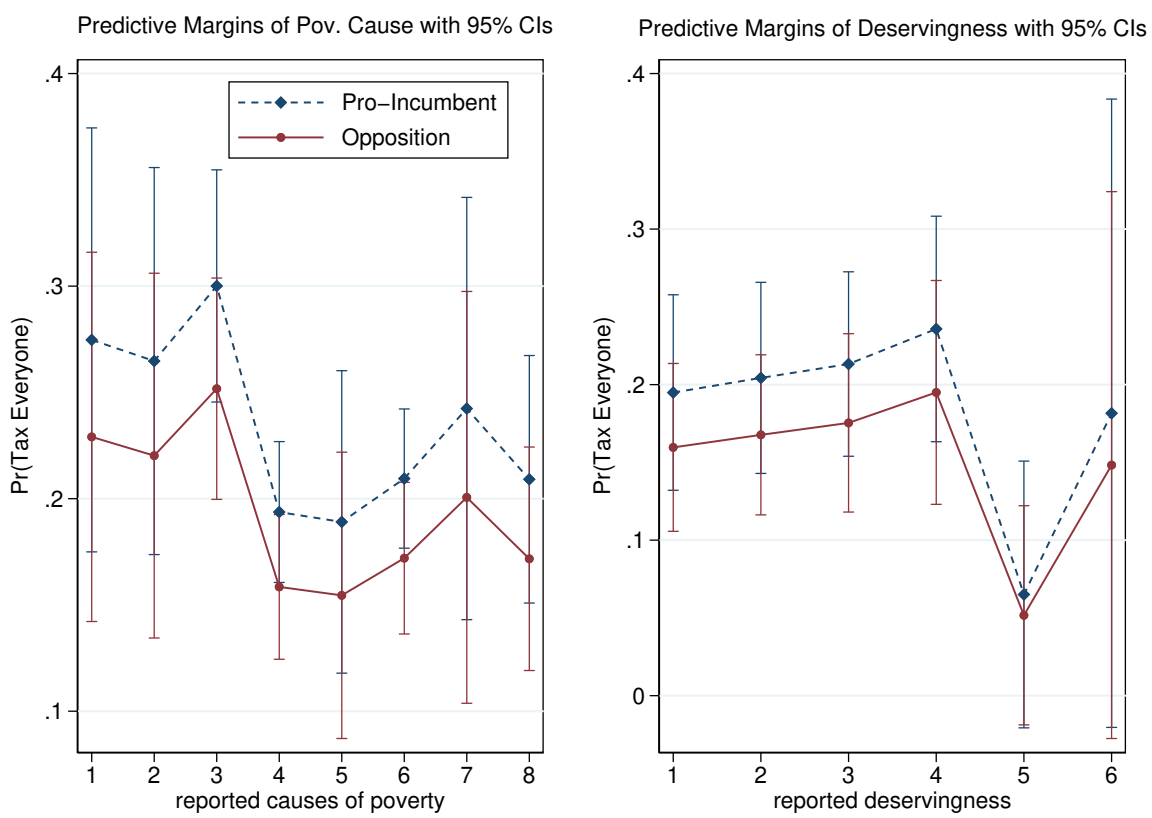

Notes: Graphs show predictive margins at different views on the causes of poverty (left) and deservingness (right), with opinion on taxing everyone as the outcome. Supporters of the incumbent president are consistently more likely to support taxing everyone to finance cash transfers. 


\section{List of Figures}

Figure 1: Increasing Domestic Investment in Social Protection in Kenya Figure 2: Partisanship and Reported Causes of Poverty

Figure 3: Partisanship and Reported Deservingness

Figure 4: Reported Causes of Poverty by Partisanship (single response)

Figure 5: Predictive Margins: Increasing VAT to Finance Cash Transfers

Figure 6: Predictive Margins: Taxing Everyone to Finance Cash Transfers 